\title{
How Do Firms Use Cash Tax Savings? A Cross-country Analysis
}

\begin{abstract}
Avoiding cash taxes can serve as a significant source of additional cash flows for firms, though how managers utilize these funds and the resulting consequences remain open empirical questions. We provide answers by examining the association between the amount of cash tax savings and two uses of cash - investment and dividend payout - for an international sample of firms. We find that firms are more likely to invest cash tax savings rather than distribute them in the form of dividends and that this results in inefficient overinvestment. We find that our results hold for an international sample of domestic-only firms, distinguishing our study from US-only studies, which focus on constraints and distortions of multinational corporations in a worldwide tax system. We find nuanced results when partitioning on country-level governance. Our results suggest cash tax avoidance has real effects on firm decisions, namely investment and payout policies, and this effect varies based on the country in which the firm operates.
\end{abstract}

JEL classifications: M41, H20, G31, G30

Keywords: cash tax avoidance, investment, dividend payout, corporate governance 


\section{How Do Firms Use Cash Tax Savings? A Cross-country Analysis}

\section{Introduction}

In this study, we examine how firms utilize cash generated via tax avoidance. Some of the most important economic and financial decisions facing management and the firm involve the creation, management, and use of cash. Relatedly, income taxes, paid as a percentage of pre-tax profits, are often one of the larger outflows of cash, and thus, the reduction of income taxes paid could serve as an important source of cash. Recent studies find that firms are successful at avoiding cash taxes (Dyreng, et al. 2008) and that tax avoidance (e.g., tax savings) is associated with greater cash flows and cash holdings (Dhaliwal et al. 2011, Hanlon et al. 2017). Therefore, to the extent that effective tax planning reduces the amount of cash taxes paid, cash tax savings may act as an important source of cash, which can have a significant effect on the firm's cash management policy. However, the real impact that cash tax savings has on the uses of cash remains an open empirical question. ${ }^{1}$

To study our research question, we use an international sample and focus our examination on the effect that an increase in cash tax savings has on the following real activities: cash holdings, investment, investment efficiency, and dividend payout policies. We focus on these activities due to data availability for the international sample. ${ }^{2}$ Prior research has used the globally-unique setting ${ }^{3}$ of US-domiciled multinational firms to test the effect that greater transaction costs associated with the US worldwide tax system has on a subset of real activities. For example, Hanlon et al.(2015) and Edwards et al. (2016a) provide evidence that multinational firms are more likely to use locked-out cash due to repatriation costs to acquire foreign corporations overseas. Similarly, Nessa (2017) provides evidence that repatriation tax costs reduce the amount of cash US multinationals distribute to shareholders in the form of dividends.

\footnotetext{
${ }^{1}$ We note concurrent research by Guenther et al. (2017). Specifically, Guenter et al. (2017) use a US-only sample of multinational and domestic firms to examine the effect of cash tax avoidance on the level of real investment. (e.g., CapEx) and how that effect varies for financially-constrained firms.

${ }^{2}$ We note that we lack detailed loan data for the broad international sample and thus do not perform tests regarding the use of cash tax savings to pay off loans.

${ }^{3}$ Relative to territorial tax systems, worldwide tax systems are relatively scare. For example, during 2017, twentysix OECD nations had territorial tax systems, while eight (including the United States) have worldwide tax systems. With the passage of the Tax Cuts and Jobs Act of 2018, the US's tax system shifts closer to a territorial system and away from a worldwide system.
} 
To ensure that our results are not a subset of the extant US-based studies that focus on the crossborder distortions of multinational corporations, we perform all tests using two samples, a sample that includes all observations with available data and a reduced sample that removes firms with foreign operations and thus includes only domestic standalone entities (i.e., domestic-only firms). ${ }^{4}$ Using the full sample shows the overall generalizability of our results. In contrast, using the reduced sample ensures the contribution of our study is incremental to that of prior studies. In addition, because domestic-only firms' tax payments are the same whether the firm operates under a worldwide or territorial tax system, through this reduced sample we are better able to measure cash tax savings because these savings are unaffected by differences in characteristics and uses between domestic and foreign cash holdings (Hartford 1999).

In pooled OLS regressions ${ }^{5}$, we find that greater cash tax savings are associated with increases in current year cash balances, but not future cash balances, which contrasts with US-based studies that suggest that firms hold on to cash for precautionary reasons (Hanlon et al. 2017). Moreover, we find that cash tax savings is associated with greater investment, lower investment efficiency (particularly, overinvestment), and lower dividend payout. We consider the economic significance of our results. For example, in the domestic-only sample, we find that a one dollar increase in tax savings is associated with a 16-cent increase in current cash holdings, an 11 cent increase in next year's cash holdings, 15 cent increase in investment, and a six cent decrease in dividends. To our knowledge, we are the first to provide such evidence using a large sample of international firms.

Next, we exploit our international sample and explore whether firms' use of cash tax savings varies across countries. Prior research has shown that the construct governance is of importance for firm financing, investment efficiency, and signaling (e.g., Jensen 1986, Harford 1999, Dittmar et al. 2003, Dechow et al. 2008). In addition, prior literature has also found that differences across countries explain much more of the variation in governance and disclosure than do differences across firms (Doidge et al.

\footnotetext{
${ }^{4}$ For completeness, we also run our analyses and report the results using the larger international sample of both multinational and domestic firms.

${ }^{5}$ We argue that cash tax savings may result in firm-level changes to investment and payout policies that are additive or subtractive to differences in pure cash flows. For this reason, we opt to use a traditional OLS regression model to capture the effect, as opposed to the cash flow model used by Guenther et al. (2017).
} 
2007) and that agency problems and their effects are more prominent outside the US (Desai et al.2007, Blaylock 2016). This implies that governance and its effects may be a meaningful point of variation in our cross-country setting. Therefore, we test the effect of country-level governance on our main findings.

To do so, we use a country-level measure of governance, the Governance Index, from Bushman et al. (2004), which captures firm-level governance transparency within countries. We find that firms located in countries with weak governance have larger dividend payouts while also underinvesting, consistent with firms located in weak governance countries removing cash from the firm.

We also rely on findings from the prior literature to motivate additional analyses including: an investigation of the effect of cash tax savings on three subtypes of investment, an investigation of the effect of cash tax savings on a proxy for share repurchases, and an investigation of the effect of exogenous changes in statutory corporate tax rates. We also perform an extensive array of robustness checks. In general, results from these tests support our earlier test results.

Our research question and analyses rely on the belief that cash tax savings are a meaningful and unique source of funds; we argue this is the case for several reasons. First, cash tax savings may be large in nature. Throughout the world taxes are levied and paid based upon a percentage of taxable profits, ranging from a country-level mean of 15.2 percent to 39.8 percent of pre-tax profits for our sample. ${ }^{6}$ Second, firm management may find cash tax savings attractive relative to other cash-saving strategies as efforts aimed at reducing the amount of cash taxes paid may be less likely to negatively impact current operations or future profitability. For example, instead of minimizing cash taxes paid as a source of funds, management might gain access to additional cash flows by aggressively reducing current period expenses such as research and development, capital replacement, or personnel expenses. These decisions, however, will likely lead to significant operational problems in the near-term and lower profitability in the longterm (Edwards et al. 2016b; Guenther et al. 2017).

\footnotetext{
${ }^{6}$ Even at 15 percent, taxes paid has the potential to be one of the largest cash outflows facing the firm and thus the savings incurred from avoiding even a portion of that can be significant.
} 
Moreover, cash generated through cash tax savings is likely distinct from other potential financing sources for numerous reasons. First, there is evidence to suggest that not all cash is equal as the source of cash may affect its persistence and value (Dechow et al. 2008). This suggests that cash generated via tax savings may be distinct from cash generated via other means and, therefore, the use of that cash may also be different. For example, cash generated via tax savings may be subject to greater uncertainty (Hanlon et al. 2017). To the extent that tax planning activities are related to greater uncertainty and to the extent that firms hold on to cash to deal with that uncertainty, firms may be less likely to distribute that cash and prefer instead to retain it, either as liquid cash, or less liquid investment.

In addition, the characteristics of tax avoiding firms may also affect how related cash flows are used. For example, prior studies show that tax avoidance may be associated with firm governance/agency problems (Desai and Dharmapala 2006, Desai et al.2007) and information opacity (Balakrishnan et al. 2017, Kerr 2018). A large literature in finance shows that information asymmetry between management and outsiders as well as governance and agency problems lead firms to undertake suboptimal levels of investment (see Hubbard 1998 and Stein 2003 for a review of these studies). Therefore, firms with significant cash tax savings may be more likely to engage in investment policies which are inefficient, resulting in empire building and/or the expropriation of shareholder wealth.

Our study is most closely related to Edwards et al.(2016b) and concurrent research by Guenther et al. (2017), both of which examine firms' use of cash savings within the context of constraints. Edwards et al. (2016) find the firms' cash tax savings are positively associated with firms' level of investment. ${ }^{7}$ Guenther et al. (2017) compare how cash tax savings are used relative to other cash flow sources and find that financially constrained firms are more likely to use cash tax savings to fund real investment. Because we use an international sample of firms, our focus is broader than these previous studies that focus on a US-only sample of multinational and/or domestic firms. A unique characteristic of our study is our ability to test differences that may arise due to variation at the country-level, such as governance and tax rate

\footnotetext{
${ }^{7}$ These results are reported in an online appendix, as the authors' primary question relates to the association between financial constraints and cash tax savings.
} 
changes. To the extent that governance, tax avoidance, and investment policies are interrelated, and to the extent that meaningful variation in governance occurs at the country-level (Doidge et al. 2006), our study aims to provide better understanding of how firms' use cash tax savings.

Our study offers several contributions to the literature. First, we contribute to the stream of literature that examines the consequences of tax avoidance (e.g., Rego and Hutchens 2015, Hanlon et al. 2017) and respond to observation made in Hanlon and Heitzman (2010, p.148) that "few studies in accounting test the effect of taxes on investment." In particular, we provide evidence that firms' cash tax savings activities have an effect on the real activities of the firm, specifically on investment, investment efficiency, and payout policies. In particular, we provide evidence that the real effects of cash tax savings are incremental to and distinct from the effects of non-tax-savings cash sources. In addition, we use a broad, large-sample international setting, one which is under-investigated in a literature which is dominated by US-only studies. In addition, and in contrast to Hanlon et al. (2017), who use a US-only setting, our results suggest that firms in other countries continue to invest and indeed, overinvest, cash tax savings (in lieu of holding onto cash tax savings to satisfy future tax-related claims).

We also contribute to the literature on tax avoidance and managerial opportunism by providing evidence that the effect on overinvestment and dividend payout varies based upon country-level governance. In doing so, we help to reconcile the conflicting results between Desai et al. (2007) and Blaylock (2016). Accordingly, our results suggest that studies examining the governance view of tax avoidance should consider the role of country-level governance in addition to firm-level governance.

The remainder of the paper proceeds as follows. Section 2 discusses our research question and hypothesis development. Section 3 describes our research methodology. Section 4 describes our sample selection and descriptive statistics. Section 5 presents our main empirical findings. Section 6 presents additional analyses and Section 7 provides concluding remarks.

\section{Prior Literature and Hypothesis Development}

\subsection{Firms' Use of Cash Tax Savings}


Our research focuses on firms' use of cash tax savings to fund investment or payout decisions. In a study of the association between cash tax savings and financial constraints, Edwards et al. (2016b) provide evidence that the firms' cash tax savings are positively associated with firms' level of investment. Our study is also related to concurrent research by Guenther et al. (2017), who use a US-domiciled sample of multinational and domestic firms, to investigate how firms use cash tax savings in the face of financial constraints.

Similar to those studies, we argue that cash tax savings generated via tax avoidance can be a meaningful source of cash flows that can be used to fund real decisions, namely the investment or payout decision. The pecking order theory, developed by Myers and Majluf (1984), suggests that firms prioritize their sources of financing, preferring internal financing sources to external financing sources. This preferential order arises because, when the prospects or risks of a firm cannot be verified by outsiders, potential investors face the risk of adverse selection and thus demand discounts on new securities. This asymmetric information leads firms to prioritize their sources of financing to minimize these costs when funding new projects such that firms prefer internal financing over other forms of financing (e.g., equity, bonds, and loans) as it imposes no asymmetric information costs.

One potentially important internal source of financing is cash tax planning as managers implement strategies to reduce taxes paid. Relying on the pecking order theory, we hypothesize that, all else equal, cash tax savings will result in cheaper funds available for investment purposes as cash tax savings generate additional internal funds and reduce the overall cost of capital. Generating cash via tax planning may be an attractive source of internal financing because, unlike other cost-cutting techniques, i.e., reducing research and development or advertising expenditures, reducing firms' taxes paid is less likely to negatively affect the firm's operations. This is highlighted in Edwards et al. (2016b), which provides evidence that financially constrained firms may rely on cash tax planning to generate additional funds because external financing sources are costlier and more difficult to acquire for these firms.

We also explore whether firms distribute cash tax savings in the form of dividends. Existing theories offer two competing arguments, and thus we do not make a directional prediction. Agency theory 
predicts that firms pay dividends to reduce the agency costs associated with free cash flows (Jensen 1986). Specifically, distributing the cash to shareholders prevents managers from investing in low net present value projects or wasting funds on perquisites. Thus, managers may prefer to distribute cash tax savings to investors to signal that they are not engaging in opportunistic cash tax avoidance, resulting in cash tax savings being positively associated with dividend payout. Alternatively, because external funds are more costly than internal funds, firms may be less likely to distribute cash tax savings as dividends if they have positive net present value projects available (Myers and Majluf 1984, Fama and French 2001). Under this scenario, greater cash tax savings would be negatively associated with dividend payout as it would be used to fund investment instead.

At this juncture it is also important to note the tension provided by Hanlon et al. (2017) to our research questions. Specifically, Hanlon et al. (2017) find evidence that US firms may hold onto cash to satisfy future claims by US tax authorities on aggressive tax positions. Because greater cash tax savings are likely associated with a greater incidence and amount of future claims by taxing authorities, this implies that cash made available through tax avoidance activities may be treated differently and thus unavailable for investment or payout purposes. If firms worldwide hold cash for precautionary reasons (Opler et al. 1999), we would observe an association between cash tax savings and cash levels but fail to observe a subsequent association between cash tax savings and investment or dividend payouts.

\subsubsection{Investment Efficiency and Firms' Use of Cash Tax Savings}

After investigating the impact of cash tax savings on investment levels, we examine its effect on investment efficiency. We do so because prior literature has shown that firms may deviate from optimal investment policies when additional funds are available and when principal-agent incentives diverge (Biddle et al.2009). This would be of importance for cash generated via tax savings as tax avoidance

relies on opacity (Kerr 2018) and can be complementary to rent extraction (Desai and Dharmapala 2006), both of which are indicative of greater principal-agent conflicts.

Furthermore, to the extent that firms have additional cash flows from tax avoidance, managers' willingness to overinvest, in particular, may be driven by the unique aspects of tax-related class flows. 
For example, the prior literature suggests that corporate tax avoidance is associated with greater corporate opacity because opacity allows firms to conceal the specific mechanisms used to avoid taxes (Balakrishnan et al. 2017). In addition, Biddle et al. (2009) suggest that lower transparency reduces overall investment efficiency.

However, it is important to note that the ultimate effect of greater cash tax savings on investment efficiency likely depends on the firm's prior level of investment efficiency. For example, if, ex ante, the firm is at an inefficient level of investment due to underinvestment, then the greater investment induced by cash tax savings could result in more efficient levels of investment. In contrast, if the firm is at a level of either efficient or overinvestment, then the greater investment would result in lower investment efficiency. Therefore, we are, ex ante, unable to make a prediction regarding the association between cash tax savings and investment efficiency.

\subsection{Country-Level Governance and Firms' Use of Cash Tax Savings}

Prior studies also suggest that governance is an important factor in a firm's investment efficiency and payout decisions (i.e., La Porta et al. 2000, Dittmar et al. 2003). To this end, we follow prior literature and include a measure of firm-level governance in all regressions. However, Doidge et al. (2007) show that differences across countries explain much more of the variation in governance and disclosure than do differences across firms, suggesting that the effect of country-level governance is an important factor. We note, however, that the single-country focus of the extant studies does not allow them to test this effect. Thus, we examine whether the use of cash tax savings is affected by country-level governance.

For these tests we focus on the firm's degree of over- or under-investment (Biddle et al. 2009). While we expect that differences in country-level level governance will be associated with investment efficiency, it is ambiguous whether the effect will result in over- or under-investment. For example, in weak-governance countries, weak-shareholder protections may allow managers to use the cash tax savings to engage in more empire-building (see Jensen 1986) and thus more overinvestment.

Alternatively, in weak-governance countries, managers may be more likely to remove cash tax savings from the firms due to weak-shareholder protections, thus leaving less cash to invest. This 
argument is supported by Dhaliwal et al. (2011), which find that weakly-governed firms that engage in greater tax avoidance have lower cash balances. This suggests that managers use tax avoidance to extract cash tax savings when firm-level governance is weak.

For dividend payout decisions, the effect is similarly ambiguous. La Porta et al. (2000) present two contrasting views on the association between country-level governance and dividend payouts. The first view suggests that dividends are an outcome of the legal protection of shareholders. This view suggests that shareholders in weak-governance countries lack the legal powers to force companies to distribute cash, and thus, we would expect firms in low-governance countries to be less likely to use cash tax savings to pay dividends.

The alternative view, also presented in La Porta et al. (2000), suggests that dividends provide a substitute for the legal protection of shareholders. Thus, under this view, we would expect firms in weakgovernance countries to be more likely to use cash tax savings to pay dividends in order to build a reputation for the fair treatment of shareholders. Following Desai and Dharmapala (2006), which show that tax avoidance and rent extraction are complementary, dividends may act as an important signal to investors that management is not using tax avoidance to extract rents from the firm. For example, Blaylock (2016) finds, for a sample of US firms, that greater tax avoidance is associated with fewer payouts to shareholders (regardless of firm-level governance). These results may be due to the fact that US shareholders already enjoy relatively strong legal protections; therefore, it is not as critical for those firms to distribute cash tax savings in the form of dividends in order to establish a reputation for the fair treatment of shareholders. How this association varies with country-level governance, however, is unknown.

Finally, within the tax literature, a firm's investment and dividend policies have been used as proxies for managerial opportunism in order to test the governance view of tax avoidance. The governance view of tax avoidance suggests that aggressive tax avoidance facilitates managerial opportunism by obfuscating the underlying purpose of the transaction, thus allowing managers to extract rents (i.e., cash and other personal benefits) from the firm (Desai and Dharmapala 2006, Desai et al. 
2007). Desai et al. (2007) find empirical support for this theory using a Russian setting. ${ }^{8}$ However, Blaylock (2016) fails to find empirical support for this theory in a US setting; specifically, he fails to find that firm-level governance affects the relationship between tax avoidance and firms' investment and payout decisions. This suggests that the discrepancy between the two studies' findings may be due to the differences in the country-level governance environments of the US and Russia. Although the goal of our study is not to evaluate the validity of the agency cost view of tax avoidance per se, the results of tests using country-level governance may also help to provide evidence to reconcile the findings within the extant literature which are otherwise at odds with each other.

\section{Research Methodology}

\subsection{Measuring Cash Tax Savings}

We calculate the amount of cash tax savings by firm-year as the amount of actual cash taxes paid benchmarked against the amount of cash taxes expected to be paid. We calculate the amount of cash taxes expected to be paid by multiplying a firm's pre-tax income by its country's enacted corporate statutory tax rate. ${ }^{9}$ To eliminate the effect of differences in scale, we then divide that difference by firm-level pretax income. This results in the following estimation equation:

$$
\operatorname{CTS}_{i, t}=\quad\left(\left[\operatorname{CSTR}_{c, t} * P T I_{i, t}\right]-\text { CashTaxPaid }_{i, t}\right) / P T I_{i, t}
$$

In Equation (1a), $C T S_{i, t}$ is the amount of firm-level cash tax savings, $C S T R_{c, t}$ is the country-level enacted corporate statutory tax rate, $P T I_{i, t}$ is firm-level pre-tax income, and CashTaxPaid ${ }_{i, t}$ is the firmlevel cash taxes paid (where subscripts $c, i$, and $t$ denote country, firm, and year, respectively). An algebraic reordering of terms (first by dividing through and then by canceling terms) results in the following series of equations.

$\operatorname{CTS}_{i, t}=\quad\left(\operatorname{CSTR}_{c, t} * P T I_{i, t} / P T I_{i, t}\right)-\left(\operatorname{CashTaxPaid}_{i, t} / \mathrm{PTI}_{i, t}\right)$

\footnotetext{
${ }^{8}$ Desai et al. (2007) do not specifically test the association between tax avoidance and investment or dividend payouts. Rather, they look at the stock market reaction around the announcement of more aggressive tax enforcement by the Russian government after the election of Vladimir Putin.

${ }^{9}$ Our results remain unchanged using ten alternative benchmarks. See the robustness section for details.
} 
The second term in Equation (1c) is commonly referred to as the cash effective tax rate, cash ETR, or CETR. ${ }^{10}$ Furthermore, subtracting the CETR from a country's enacted statutory rate for the year is similar to the benchmarking done in prior international tax studies such as Amiram et al. (2017) and Kerr (2018) and reflects the cash ETR spread. We use Equation (1c) to calculate our measure of cash tax savings (CTS).

\subsection{Firms' Use of Cash Tax Savings}

We begin by investigating the relationship between a firm's cash tax savings and its cash balances and changes. Specifically, we use ordinary least squares (OLS) to regress either the change in cash from year $t-1$ to year $t$ or the end of year cash balance scaled by beginning period total assets on cash tax savings (CTS). We include additional control variables based on Dhaliwal et al. (2011). We expect cash tax savings to be associated with more cash available to the firm and thus a positive coefficient on CTS. We perform this analysis for the current and subsequent two years to see how cash tax savings persists into future cash balances and changes.

For this, and all subsequent OLS regressions, we cluster standard errors at the firm level to account for possible correlation in residuals, though our results remain qualitatively unchanged if, instead, we cluster by firm and year (see Gow et al. 2010) or use heteroskedastic-robust standard errors. Where appropriate, we also include fixed effects at the country, industry, and year levels, where industry fixed effects are based at the two-digit Industry Classification Benchmark level. These fixed effects control for otherwise unobserved or difficult to measure factors that could potentially confound the regression results.

\footnotetext{
${ }^{10}$ Dyreng et al. (2008) use a long-run CETR computed over a multi-year horizon. Because of gaps in the data for our sample and the need for other controls which would drastically reduce our sample size, we are confined to using a yearly CETR measure and thus the yearly spread between the country-level statutory tax rate and the firm-level CETR.
} 
Next, we examine how firms use their cash tax savings by testing the association between CTS and two potential uses: investment activities and dividend payouts to shareholders. For this analysis we separately estimate OLS regressions of the following form:

$$
\begin{aligned}
& \text { Invest }_{i, t}=\quad \beta_{0}+\beta_{1} \text { CTS }_{i, t-1}+\beta_{2} \text { CloseShares }_{i, t-1}+\beta_{3} A Q_{i, t-1}+\beta_{4} \sigma C F O_{i, t-1}+ \\
& \beta_{5} \sigma \text { SALE }_{i, t-1}+\beta_{6} \text { olnvest }_{i, t-1}+\beta_{7} \text { Size }_{i, t-1}+\beta_{8} \text { OverFirm }_{i, t-1}+ \\
& \beta_{9} \text { OpCycle }_{i, t-1}+\beta_{10} \text { Losses }_{i, t-1}+\beta_{11} \text { Foreign }_{i, t-1}+\beta_{12} P P E_{i, t-1}+ \\
& \beta_{13} B M_{i, t-1}+\beta_{14} \text { DivDummy }_{i, t-1}+\beta_{15} A g e_{i, t-1}+\beta_{16} Q_{i, t-1}+\varepsilon_{\mathrm{i}, \mathrm{t}} \\
& \operatorname{DivPay}_{i, t}=\quad \beta_{0}+\beta_{1} \text { CTS }_{i, t}+\beta_{3} \text { CloseShares }_{i, t}+\beta_{4} A Q_{i, t}+ \\
& \beta_{5} \sigma C F O_{i, t}+\beta_{6} \sigma \operatorname{SALE}_{i, t}+\beta_{7} \text { Size }_{i, t}+\beta_{8} \text { BM }_{i, t}+\beta_{9} \text { CFConst }_{i, t}+ \\
& \beta_{10} \operatorname{Cash}_{i, t}+\beta_{11} \operatorname{Age}_{i, t}+\varepsilon_{\mathrm{i}, \mathrm{t}}
\end{aligned}
$$

In Equation (2a), we model both total investment and inefficient investment as a function of cash tax savings and other controls (see Biddle et al. 2009), testing each separately. In addition, we follow Cheng et al. (2013) and lag the right-hand side variables. We measure total investment, Invest, as the sum of research and development expenditures, capital expenditures, and acquisitions less dispositions of property, plant, and equipment, all deflated by lagged total assets. Invest is designed to capture both capital and non-capital investment. We also modify the Biddle et al. (2009) model by adding our measure of cash tax savings, CTS. When Invest is the dependent variable, a positive coefficient on CTS is consistent with firms using cash tax savings to fund investment. ${ }^{11}$

Because prior literature suggests that firm-level corporate governance may affect investment (Biddle et al. 2009, Cheng et al. 2013), we include two variables to control for firm-level governance. ${ }^{12}$ First, we use CloseShares, defined as the number of closely-held shares divided by total shares

\footnotetext{
${ }^{11}$ One possible explanation for a negative coefficient on CTS would be that managers are extracting cash from the firm, and thus have less cash to invest (Dhaliwal et al. 2011).

${ }^{12} \mathrm{We}$ are unable to use the G-Score (Gompers et al. 2003) and the E-Score (Bebchuk et al. 2009) governance measures because they are only available for US firms.
} 
outstanding as a firm with a higher concentration of inside shareholders is more likely to suffer from governance issues. We also use a measure of financial reporting and accruals quality $(A Q)$ based on Dechow and Dichev (2002) and Biddle et al. (2009). Biddle et al. (2009) find that financial reporting quality is positively related to overall investment, and negatively related to under- and overinvestment.

As additional controls, we include variables likely to affect investment (see Biddle and Hilary 2006, Liu and Wysocki 2007, Biddle et al. 2009), including: cash flow volatility ( $\sigma C F O)$, sales volatility $(\sigma S A L E)$, investment volatility ( $\sigma I N V E S T)$, firm size $(S I Z E)$, market-to-book ratio $(B M)$, capital intensity $(P P E)$, and dividend activity (DivDummy). We include a control for the firm's likelihood of overinvesting (OverFirm) based on overall cash and leverage. We also include controls for firm operating cycle (OpCycle), age (Age), and loss position (Losses) as firms may have different investment needs depending on their life cycle and business stage (Dechow 1994, Dechow et al. 1998, Dechow and Dichev 2002). Finally, we include an indicator variable (FOREIGN), based on foreign sales, assets, or net income, and Tobin's $\mathrm{Q}(Q)$ as a measure of foreign activity and growth opportunities, respectively, as firm with foreign operations and greater growth opportunities are more likely to invest. All variables are defined in the Appendix.

Equation (2b) tests whether firms distribute cash tax savings to shareholders in the form of a dividend. We adopt and modify the model used in DeAngelo et al. (2006) and Blaylock (2016). The dependent variable, DivPay, is replaced by one of two measures designed to capture the firm's distributions to shareholders. The first is CashDiv and is computed as cash dividends paid scaled by total assets. The second is Payout, which is defined as dividends less the gain or loss on the sale of stock divided by lagged total assets. Similar to Equations (2a) and (2b), the primary variable of interest is CTS. When CashDiv or Payout is the dependent variable, a positive coefficient on CTS is consistent with firms distributing cash tax savings to shareholders in the form of dividends. Alternatively, a negative coefficient is consistent with firms retaining cash savings in the firm rather than paying it out to shareholders.

Consistent with the prior studies, all variables used in the payout regressions are measured contemporaneously. 
We also control for other variables that are associated with a firm's payout decision (see DeAngelo et al. 2006). Similar to the investment analysis, we control for insider ownership (CloseShares) and financial reporting quality $(A Q)$. We also add controls for: cash flow volatility $(\sigma C F O)$ and sales ( $\sigma S A L E S$ ) volatility to control for the need to hold larger cash to reduce the costs of financial distress; book-to-market $(B M)$ to control for investment opportunities; and size (Size) and cash (Cash) to control for the amount of cash available to be paid out at the beginning of the year. We also add an indicator variable, CFConst, to capture firms that are cash flow-constrained, and thus less able to pay dividends. Lastly, we control for firm age (Age), as dividend payouts are likely to vary based on firm life cycle.

\subsubsection{Investment Efficiency and Firms' Use of Cash Tax Savings}

Next, we examine the efficiency of firms' investment decisions. To test whether firms' cash tax savings is associated with greater investment efficiency, we replace Invest in Equation (2a) with the absolute value of investment efficiency (absInvestEff). absInvestEff is calculated following Biddle et al. (2009) and Cheng et al. (2013) and is designed to capture deviations from expected investment (i.e., overor underinvestment). We follow Biddle et al. (2009) and compute absinvestEff as the absolute value of the residuals obtained from the following model, estimated by country-industry-year:

Invest $_{i, t+1}=\beta_{0}+\beta_{1} *$ SalesGrowth $_{i, t}+\varepsilon_{i, t+1}$

where Invest is total investment, as previously defined, and SalesGrowth is the percentage change in sales from year $t-1$ to year $t$. When absInvestEff is used as the dependent variable in Equation (2a), a positive coefficient on CTS is consistent with less efficient investment because it signifies great over- or under investment, whereas a negative coefficient on CTS is consistent with more efficient investment.

\subsection{Country-Level Governance and Firms' Use of Cash Tax Savings}

To examine the effect of country-level governance on investment and dividend payouts, we modify Equations (2a) and ( $2 \mathrm{~b}$ ) by adding a measure of country-level governance. To proxy for countrylevel governance we use LowGov, which is an indicator variable set equal to one if the firm is located in a country in the lowest tercile of the governance index as found in Bushman et al. (2004). The governance 
index captures the quality of the corporate reporting environment in each respective country. Specifically, the index captures the comprehensiveness of firm disclosures related to the identity of managers, the identity of board members and their affiliations, compensation of officers and directors, share ownership by directors and employees, the identity of major shareholders, and the range of shareholding. ${ }^{13}$

We interact the variable, LowGov with our tax savings variable, CTS. To test the effect of governance on investment efficiency, we use the modified Equation (2a). When absInvestEff is the dependent variable, a positive coefficient LowGov Interaction is consistent with firms in weak governance countries engaging in less efficient investment (e.g., either overinvesting or underinvesting).

To test the effect of governance on dividend payouts, we modify Equation (2b) by including the interaction between LowGov and CTS. In the payout model, when CashDiv or Payout is the dependent variable, a positive coefficient on LowGov Interaction is consistent with firms in weak governance countries using cash tax savings to pay dividends and supports the reputation argument offered by La Porta et al. (2000). Alternatively, a negative coefficient on LowGov Interaction is consistent with firms in weak countries using cash tax savings for purposes other than paying dividends, and thus is consistent with the agency argument presented in La Porta et al. (2000).

\section{Sample Selection and Descriptive Statistics}

\subsection{Sample Selection}

We obtain firm-level fundamental and financial variables from Thomson Reuters Datastream Advanced Database, specifically Worldscope. In addition, country-level data on statutory tax rates is obtained from the Organization for Economic Co-operation and Development (OECD) website. We start with all firm-year observations with available data between the years 1993 and 2011. Our analysis begins

\footnotetext{
${ }^{13}$ We also use an alternative measure of country-level governance, the anti-self-dealing index (Djankov et al., 2008). The measure captures the extent to which minority shareholders are protected from expropriation (or tunneling) from managers within each country. In general, we find consistent results.
} 
in 1993 due to the general lack of tax-related data on Worldscope prior to that time. We manually collect data from Datastream, and thus our analysis is stopped at 2011 due to the amount of time necessary to manually collect the data, as well as the lag between year-end and when the data is available to collect. Because lagged variables, such as total assets, are used in the measurement of variables, the year 1993 is essentially eliminated from the analysis. We include all observations available for each test, though sample sizes between tests may differ due to additional data restrictions.

Along with this full sample, we also remove firms with foreign operations from the sample such that this reduced sample includes only domestic standalone entities (“domestic-only firms"). We do so for two reasons. First, the relation between cash tax savings and investment and payout policies is not confounded by multinational tax concerns for this subset of firms. Second, we are able to better measure cash tax savings for this subset of firms because these savings are unaffected by differences in characteristics and uses between domestic and foreign cash holdings (Hartford et al. 2017).

\subsection{Descriptive Statistics}

Table 1 reports our sample composition by country for both multinational and domestic-only firms. Firms located in the United States and Japan comprise the largest portion of our sample. ${ }^{14}$ The US and Japan also have the highest average statutory tax rates during the sample period (39.3 percent and 39.8 percent, respectively). ${ }^{15}$

\section{[Insert TABLE 1 here]}

Table 2, Panels A and B report the firm-level descriptive statistics for our international sample of all firms (e.g., multinational and domestic) firms and domestic-only firms. We include the descriptive statistics for the full sample for completeness but focus on attention on the descriptive statistics reported in Panel B for the domestic-only sample. In Panel B, the mean and median of CTS is positive (0.015 and

\footnotetext{
${ }^{14}$ We conduct our analyses excluding the United States and Japan and find consistent results.

${ }^{15}$ We make two notes here. First, the reported CSTRs reflect a blending of federal and local rates. This is consistent with other international tax studies (see Amiram et al. 2017 and Kerr 2018). Second, in 2012, Japan reduced its corporate statutory rate; however, because 2012 is not part of our sample period, our results are not affected by the rate change. In 2017, the US reduced its corporate statutory rate to 21 percent; the rate change will go into effect January 1, 2018. Again, this rate change does not affect our sample.
} 
0.078, respectively) suggesting that firms report cash effective tax rates that are lower than their country's statutory rate, which is consistent with Kerr (2018). The mean (median) value of Invest is 9.4 percent (5.8 percent) of prior year's assets. The mean and median values of absInvestEff are 0.063 and 0.040 , respectively. Last, firms pay out a mean (median) cash dividend that is 1.6 percent ( 0.8 percent) of total assets.

\section{[Insert TABLE 2 here]}

Table 3 reports the correlations between the variables with the correlations below the diagonal being for the full sample and those above the diagonal being for the domestic-only sample. As the domestic-only sample has no foreign operations, the foreign indicator variable here and in all future tables is omitted from the domestic-only regressions. For both samples, CTS is significantly and positively correlated with Invest, suggesting that cash tax savings is associated with greater investment. Moreover, CTS is significantly and positively correlated with absInvestEff, again for both samples, suggesting that greater cash tax savings is associated with less efficient investment. Taken together, the correlations suggest that firms use cash tax savings to fund investment, but their investment decision is not optimal. Last, for both samples CTS is significantly and negatively correlated with DivPay, suggesting that high tax savings firms pay fewer cash dividends. We next turn to multivariate tests.

[Insert TABLE 3 here]

\section{Multivariate Results}

We conduct all our analyses using the full sample of international firms and our sample of domestic-only firms. We note that, in general, results are consistent across both samples.

\subsection{Cash Tax Savings and Cash Holdings}

We begin by investigating a firm's cash holdings and the relationship between cash and cash tax savings for our international sample of firms. Table 4 reports the results of this test. As seen in Columns (1) and (4), the coefficient on CTS is positive and significant, indicating that greater tax savings is 
associated with larger cash holdings. In terms of economic significance, we find that a one dollar increase in tax savings is associated with roughly a 16-cent increase in current cash holdings. We observe similar results in both the full and domestic-only samples. This suggests that tax savings increase the firm's available cash and is consistent with the argument in Edwards et al. (2016b).

Next, we test the relationship between current cash tax savings and future cash. This is important because if current period tax savings is also positively associated with future cash then this implies that firms hold onto their cash tax savings rather than use them for other purposes. As seen in Columns (5) and (6), we find that 1-year and 2-year forward cash holdings are not associated with current cash tax savings for the domestic-only sample. These results show that the association between cash tax savings and cash holdings is transitory, implying that firms make use of the cash from tax savings rather than holding it as observed in Hanlon et al. (2017). ${ }^{16}$ In particular, for the average firm, we find that a one dollar increase in cash tax savings is associated with a 16-cent increase in current year cash tax holdings, an 11-cent increase in the next year cash holdings, and no increase in the two-year ahead cash holdings. ${ }^{17}$

[Insert TABLE 4 here]

\subsection{Firms' Use of Cash Tax Savings}

As the previous results show that cash from cash tax savings appears to be transitory, we next explore two potential uses: investment and payout. Table 5, Panel A reports results of the investment analysis. Again, we find consistent results in both samples, namely that firms with great cash tax savings have higher amounts of investment. Specifically, in Column (2), the coefficient on CTS is positive and significant (coefficient of 0.007 ), suggesting that the increase in investment observed is not being driven by distortions from cross-border tax considerations, implying that cash tax savings are driving the result.

\footnotetext{
${ }^{16}$ We note that in untabulated analyses we use changes in cash instead of levels of cash. Our findings remain consistent regardless of measure.

${ }^{17}$ These calculations are performed by multiplying the coefficient on the variable of interest by the average ratio of the denominators for the dependent and independent variables of interest.
} 
In addition, the effect is incremental to both other cash flow effects and the propensity of the firm to overinvest regardless of the level of cash tax savings ( $\sigma C F O$ and OverFirm). This implies that cash tax savings exacerbates the overinvestment of cash documented in the prior literature (see Hubbard 1998 and Richardson 2006) and, therefore, provides support for our argument that cash generated through tax savings (and its accompanying effects) are distinct from other sources of cash (and their accompanying effects). In terms of economic significance, this implies that a one dollar increase in tax savings is associated with roughly a 15 -cent increase in investment.

Table 5, Panel B reports the results of our dividend payout analysis. Again, we find results consistent in both the full and domestic-only samples. Specifically, in Column (5) the coefficient on CTS is negative and significant, suggesting that firms with greater cash tax savings pay less cash dividends. We find a similar result in Columns (6) through (8), when we use Payout or an indicator variable (DivDummy) as the dependent variable. These results suggest that, on average, firms with greater cash tax savings actually shift away from paying dividends. In terms of economic significance, these findings imply that a one dollar increase in tax savings is associated with roughly a six-cent decrease in dividends.

We make an important note at this juncture. Specifically, our overall research question is to investigate how firms use cash tax savings. A simplistic view of this research question might be that more available cash means the potential for an increase in all cash-using activities. However, the negative coefficient here seems to suggest that firms with greater cash tax savings do not just merely increase cashusing real activities, but rather have fundamental shifts in the real activities they engage in which transcends mere cash flow effects. This result further strengthens the argument that cash from tax savings are distinct from other sources of cash. The results above are also consistent with the findings in Blaylock (2016) and suggest that, on average, firms reinvest cash tax savings back into the firm rather than paying out to shareholders in the form of dividends.

[Insert TABLE 5 here]

\subsubsection{Cash Tax Savings and Investment Efficiency}


We next investigate the impact that cash tax savings has on firms' investment efficiency. Table 6 reports the results of our investment efficiency analysis. Using absInvestEff as the dependent variable, we find results consistent in both the full and domestic-only samples. Specifically, Column (3) shows a statistically significant and positive coefficient (coefficient of 0.002) on CTS, suggesting that firms use of cash tax savings for investment purposes is associated with less efficient investment. Again, we note that the effect of cash tax savings on investment efficiency is incremental to both other cash flow effects and the propensity of the firm to overinvest regardless of the level of cash tax savings ( $\sigma C F O$ and OverFirm).

We also note that while these results suggest that greater cash tax savings is associated with lower investment efficiency, it remains unclear whether this decrease in efficiency is due to over- or underinvestment. To address this ambiguity, we conduct an additional analysis. Specifically, we conduct an additional analysis using a multinomial logit model. To conduct this analysis, we rank the signed investment efficiency into quartiles - the top quartile captures over-investment, the bottom quartile captures under-investment, and the middle two quartiles capture "normal" investment (our baseline) and use these rankings as our dependent variable. The multinomial logit model then separately compares the over-investment and under-investment quartiles to the two baseline quartiles. Therefore, a positive coefficient on CTS for the over-(under-)investment versus normal is consistent with firms over-(under-) investing cash tax savings.

We find that our results remain mostly unchanged across samples. Specifically, for the domesticonly sample we find a positive and significant coefficient on CTS in the Over vs Normal model (coefficient of 0.114), and an insignificant coefficient on CTS in the Under vs Normal model and that these are similar to results for the full sample. This finding suggests that the association between cash tax savings and investment inefficiency is driven by over-investment. In addition, and as is the case in all previous analyses, results that are consistent in both samples imply that our results are not a subset of prior findings.

In whole, the results of our analysis in Table 6 suggest that managers use additional cash tax savings to engage in empire building and that this association is not driven by distortions of multinational 
corporations and/or the US' worldwide tax system as shown by the prior literature. These findings are consistent with the agency view of tax avoidance (Desai and Dharmapala 2006, Desai et al. 2007), but inconsistent with tax avoidance being associated with relatively more optimal investment policies for US firms (Blaylock 2016). The discrepancy between the findings in Blaylock (2016) and Desai et al. (2007), combined with our results, demonstrates the importance of examining firms' use of cash tax savings across countries, rather than within a single country.

[Insert TABLE 6 here]

\subsection{Firms' Use of Cash Tax Savings and Country-Level Governance}

Under the agency view of tax avoidance, firms in areas of weaker corporate governance may be more likely to extract rents via tax avoidance. Because both investment and payout can be used as a means of extracting rents - increased payout as a direct means of extracting rents and excess investment as a signal of empire building — we test whether the association between cash tax savings and investment and payout decisions is affected by country-level governance. This analysis is motivated by the conflicting findings in Desai et al. (2007) and Blaylock (2016). Because our main regressions already control for firm-level governance, any effect found in these tests will be incremental to firm-level governance.

Table 7, Panel A, reports the results of the analysis of the effect of country-level governance on investment efficiency. In this analysis, we include a dummy variable, LowGov, for country-level governance based upon the Governance index in Bushman et al. (2004). As country fixed effects would subsume the variable of interest, we exclude those effects from these regressions. The results in Table 7 , Column (3) show the coefficient on the interaction term (LowGov Interaction) between tax savings and country-level governance is positive and significant. The sum of this coefficient with the coefficient on CTS alone suggests that firms in countries with weaker governance and regulatory environments use cash tax savings less efficiently for investment purposes when compared with firms that operate in countries with stronger governance. 
To distinguish whether this association is driven by the firm over- or under-investing, we modify our original multinomial logit model to include the interaction term LowGov Interaction. The results of this analysis are reported in Column (4) of Table 7, Panel A. We find a positive and significant coefficient on the interaction term in the Under vs Normal model and an insignificant coefficient on the interaction term in the Over vs Normal model. This finding suggests that the association between cash tax savings and investment efficiency in low governance countries is driven by under-investment, rather than overinvestment.

Table 7, Panel B, reports the results of our payout analysis. In Columns (3) and (4) the interaction is consistently positive and significant, suggesting that firms domiciled in countries with weaker governance have higher levels of both cash dividend and overall payout.

Taken together, the results reported in Table 7 suggest that firms in weak governance countries tend to underinvest and distribute cash tax savings to shareholders in the form of dividends. Although consistent with rent extraction, the findings are also consistent with the reputation building argument presented in La Porta et al. (2000). Specifically, La Porta et al. (2000) argue that managers of firms in weak governance countries may pay dividends in order to build a reputation for the fair treatment of shareholders. This serves as a signal to investors and the market that management is not using tax avoidance strategies to extract rents from the firm and thus these firms are potentially able to raise external capital at more favorable terms.

[Insert TABLE 7 here]

\section{Additional Analysis}

\subsection{Firms' Use of Cash Tax Savings and Investment Subtypes}

In this analysis, we examine another investment characteristic: firms' subtypes of investment. When investing, firms often have a portfolio of choices in which to invest, such as intangible or physical assets. In addition, prior literature suggests that intangible assets may present greater opportunities for future tax avoidance because intangible assets can be easily transferred between operating units and thus 
may also be used to shift income from high tax to low tax jurisdictions to generate future tax savings (Grubert and Slemrod 1998, Grubert 2003, Dyreng et al. 2008). Therefore, to the extent that firm investment is associated with cash tax savings, firms may prefer to invest in one type of asset over another.

To test a firm's investment preferences, we break Invest into three different components, each deflated by beginning of period total assets - capital expenditures (CapEx), measured as the capital expenditures less dispositions of property plant and equipment, non-capital expenditures (Non-CapEx), measured as the sum of research and development and acquisitions; and intangibles (Intangibles), measured as intangibles. We re-estimate Equation (2a) separately using each of the three measures as the dependent variable.

Table 8 reports the results of our analysis for the domestic-only sample using the three components of investment. Specifically, we test whether the increased level of investment is being driven by CapEx, Non-CapEx and/or Intangibles. The results of this test are shown in Table 8, Columns (1) through (3). As seen there, we find that cash tax savings is associated with increased CapEx, Non-CapEx and Intangibles. This implies that cash tax savings are used for both capital and non-capital purposes, and that firms are not investing primarily in intangible assets to facilitate future tax avoidance. ${ }^{18}$

[Insert TABLE 8 here]

\subsection{Cash Tax Savings and Share Repurchases}

Although our primary analysis focuses on dividend payouts because we rely on prior literature (i.e., Blaylock 2016), for completeness we also examine another form of distributions to shareholders: share repurchases. To estimate the effect of cash tax savings on share repurchases, we rely on Nessa (2017) to estimate the following model:

ChTreasStock $_{i, t}=\quad \beta_{0}+\beta_{1}$ CTS $_{i, t}+\beta_{3}$ Lev $_{i, t}+\beta_{4}$ CapEx $_{i, t}+$

\footnotetext{
${ }^{18}$ In untabulated analyses we find generally consistent results using the full sample: that increased investment is found in all three subtypes.
} 


$$
\begin{aligned}
& \beta_{5} \sigma C F O_{i, t}+\beta_{6} \sigma S A L E_{i, t}+\beta_{7} \text { Size }_{i, t}+\beta_{8} P P E_{i, t}+\beta_{9} B M_{i, t}+ \\
& \beta_{10} \text { DivDummy }_{i, t}+\beta_{11} \text { Age }_{i, t}+\varepsilon_{i, t}
\end{aligned}
$$

Due to data limitations in Worldscope, we use the change in treasury stock to proxy for share repurchases. The primary variable of interest in Equation (4) is CTS. A positive coefficient on CTS is consistent with firms distributing cash tax savings to shareholders via share repurchases. Alternatively, a negative coefficient is consistent with firms retaining cash savings in the firm rather than repurchasing shares. Consistent with the prior studies, all variables used in the payout regressions are measured contemporaneously.

Table 9, Columns (1) and (2) report the results of our analysis of stock repurchase activity for the full international and domestic-only samples. In both samples, we observe a positive and significant association between CTS and changes in treasury stock, which is consistent with firms using cash tax savings to repurchase shares. While the results of our primary analysis suggest that firms, on average, prefer to reinvest tax savings rather than distribute them to shareholders, our share repurchase analysis suggests that firms may distribute cash tax savings. This result may be explained by the differences between to the two payout vehicles (Guay and Hartford 2000, Jagannathan et al. 2000, Nessa 2017). Specifically, because dividends implicitly commit firms to future payout, and cash flows from tax planning may be uncertain, firms may prefer to use repurchases and therefore retain flexibility on when they choose to distribute these savings.

[Insert TABLE 9 here]

\subsection{Firms' Use of Cash Tax Savings and Corporate Statutory Tax Rates Changes}

To better identify the effect of cash tax savings on firms' investment and payout decisions, we examine the effects of corporate statutory tax rates changes at the country level. This analysis is important as it moves the tests away from association-only tests, which can be potentially confounded by firm choice and uses, and instead uses firm-exogenous changes in statutory tax rates. 
To conduct this analysis, we re-estimate Equations (2a) and (2b) where the dependent variable of interest is the change in the corporate statutory tax rate (CSTRChg) from year $t-1$ to year 1 . For the interpretation of the coefficients here to be consistent with our prior analyses, we then multiply CSTRChg by -1 so that it is increasing in greater savings. In addition, as the change in the corporate statutory tax rate is a country-level variable, we perform the regressions at the country-industry- level, as this reflects the change in focus of measuring tax savings at the country level while also allowing for a sample size with reasonable power. Accordingly, we measure all control variables in these regressions as countryindustry-year medians of firm-level observations.

Table 10 reports the results of this analysis. We find that decreases in statutory tax rates are associated with more investment and greater repurchases, which is consistent with firms using additional cash tax savings to fund these activities. This result is consistent with our primary, firm-level findings. In addition, while we find that the sign on the dividend-related coefficients are consistent with our prior results, we note that they no longer have statistical significance.

$$
\text { [Insert TABLE } 10 \text { here] }
$$

\subsection{Untabulated Robustness Tests}

\subsubsection{Two-Stage Least Squares (2SLS)}

Although prior literature often treats the choice of investment and payout as independent, the choices likely relate to and affect one another. For example, because funding investments with external funds is costly (Myers 1984, Fama and French 2002), firms may forego paying dividends if they have investment opportunities. ${ }^{19}$ Alternatively, because of the agency costs associated with free cash flows (Jensen 1986), firms may forego investment for a higher payout to help alleviate these concerns.

Although the previous literature on investment and dividend payout predominantly use OLS regressions, the reasoning above implies that investment and payout decisions may not be made in isolation from each other. Therefore, in untabulated robustness we use a 2-stage least squares (2SLS) regression approach

\footnotetext{
${ }^{19}$ Our goal is not to test the distortions of tax policy on investment or payout (see Hanlon and Heitzman 2010 for a review of this literature), but rather to test how the availability of additional cash generated via tax savings affects firms' real activities.
} 
that jointly estimates the investment and payout decisions. We find that our results, and thus our conclusions, remain unchanged using this approach.

\subsubsection{Excluding the United States and Japan}

To provide robustness to our main results, we exclude either or both the United States and Japan from the regressions using cash, dividends, investment, and investment efficiency. We do so because, as the United States and Japan contain the greatest number of firms, their presence in the sample may be unduly influencing our results. By excluding these countries, we ensure that our results are not being biased by their inclusion. Untabulated results of tests excluding these countries, either separately or together, remain qualitatively unchanged.

\subsubsection{Measuring Savings using Book Effective Tax Rates}

Although our tests have focused on the amount of cash tax savings (i.e., CTS), we also perform untabulated tests using the spread between a country's statutory tax rate and the book effective tax rate (ETR), computed as total tax expense divided by pretax income, as the variable of interest. Because we are interested specifically in cash savings through tax avoidance, we do not use this measure in our main analyses. However, because the ETR has greater data availability, it can be useful to check the veracity of our results. In general, our results are consistent using either measure, though are, at times, attenuated when using the ETR spread.

\subsubsection{Alternative benchmarks for Cash Tax Savings}

In our main analyses we use the corporate statutory rate as the benchmark against which to set the expectation on the amount of cash taxes to be paid and thus the amount of cash tax savings. However, to the extent that firms are able to routinely engage in tax savings unique to or related to the country in which they are domiciled (and to the extent that this relation is not captured by the use of either country or year fixed effects) the use of the CSTR as a benchmark may distort the amount of cash tax savings.

Although we report some evidence against this in our analysis using the change in the corporate statutory tax rate, we also perform a host of untabulated analyses. Specifically, we use ten different alternative 
benchmarks against which to measure the amount of cash tax savings: 1) the country-level mean corporate statutory tax rate, 2) the country-level median corporate statutory tax rate, 3) the country-level mean cash effective tax rate, 4) the country-year-level mean cash effective tax rate, 5) the country-level median cash effective tax rate, 6) the country-year-level median cash effective tax rate, 7) the countrylevel mean effective tax rate, 8) the country-year-level mean effective tax rate, 9) the country-level median effective tax rate, and 10) the country-year-level median effective tax rate. In all cases our results remain qualitatively unchanged.

\subsubsection{Controls for Cash}

In our main analyses we follow models from the prior literature to estimate our results. While each model controls for possible cash effects ( $\sigma C F O$, OverFirm, and CFConst), an explicit control for the level or change in cash is not present. To provide additional robustness to our interpretation that cash tax savings are distinct and incremental to other cash effects, we perform untabulated analyses that also explicitly control for either the level or change in cash. ${ }^{20}$ Our results and the interpretation of them remain qualitatively unchanged, providing additional support for our ex ante argument and ex post interpretation that cash generated via cash tax savings is different from, with the effect being incremental to, cash generated via other means.

\section{Conclusion}

We examine firms' cash tax savings and how those savings affect firm-level cash holdings, investment, and shareholder payout for an international sample of firms. We distinguish our study from US-only studies, which focus on constraints and distortions of multinational corporations in a worldwide tax system, by conducting our analyses on a sample of domestic-only firms. We find, on average, that firms with greater cash tax savings have larger, transitory cash balances, and that firms use the cash tax savings to fund investment, as opposed to paying cash dividends. This suggests that firms prefer to reinvest tax savings in the firms rather the distributing it to shareholders; this finding is consistent with

\footnotetext{
${ }^{20} \mathrm{We}$ also perform analyses using regression models that control for $C F C o n s t$ when investment is the dependent variable, both with and without controls for cash levels and changes. Our results remain unchanged.
} 
pecking order theory. Tests of firms' investment practices show that firms choose to invest cash tax savings in both capital and non-capital investments and that these firms generally tend to overinvest. When we examine the effect of country-level governance, we find that firms located in weak-governance countries pay out larger amounts of cash dividends while also underinvesting. This finding is consistent with firms located in weak governance countries removing the cash savings from the firm instead of keeping the cash savings within the firm. Moreover, our finding that firms in weak governance countries pay more in cash dividends is consistent with the reputation argument presented in La Porta et al. (2000). The results of our study offer several contributions to the literature. First, we contribute to the stream of literature that examines the consequences of tax avoidance (e.g., Rego and Hutchens 2015, Hanlon et al. 2017) by providing evidence that firms' tax avoidance activities affect other corporate decisions, specifically investment and payout policies, and that this effect varies across countries with different regulatory and governance environments. In addition, we do so using a broad, large-sample international setting, one of which is under-investigated in the current literature as the majority of studies focus on US-only samples. We also contribute to literature on the governance view of tax avoidance (i.e., Desai and Dharmapala 2006, Desai et al. 2007, Blaylock 2016) by providing evidence that the effect of governance on the relationship between tax avoidance and managerial opportunism is a country-level phenomenon. In doing so, we help to reconcile the seemingly conflicting results between Desai et al. (2007) and Blaylock (2016). 


\section{Appendix \\ Variable Definitions}

$\begin{array}{ll}\begin{array}{l}\text { Variable Name } \\ \begin{array}{c}\text { Investment: } \\ \text { Invest }\end{array}\end{array} & \begin{array}{l}\text { Variable Definition } \\ \text { The sum of research and development expenditures, capital expenditures and } \\ \text { assets in } t-1 \text { (Biddle et al. 2009). }\end{array} \\ \text { absInvestEff } & \begin{array}{l}\text { The absolute value of the error term from a regression of Invest on the } \\ \text { percentage change in sales (Biddle et al. 2009). }\end{array} \\ \text { CapEx } & \begin{array}{l}\text { Capital expenditures less dispositions of property plant and equipment, } \\ \text { deflated by total assets in } t-1 .\end{array} \\ \text { Non-CapEx } & \begin{array}{l}\text { The sum of research and development expenditures and acquisitions, deflated } \\ \text { by total assets in } t-1 .\end{array} \\ \text { Intangibles } & \text { Intangibles deflated by total assets in } t-1 .\end{array}$

DivPay:

CashDiv

Cash dividends paid scaled by total assets in year $t$.

Payout

Dividends less gain/loss on the sale of stock scaled by lagged total assets.

\section{Cash Tax Savings:}

CTS

The country's statutory tax rate less the cash effective tax rate (computed as cash taxes paid divided by pre-tax income). CTS is set to missing if pretax income is negative.

\section{Governance:}

LowGov

Indicator variable set equal to one if the firm is located in a country in the lowest tercile of Bushman, Piotroski and Smith (2004) governance index.

\section{Control Variables:} CloseShares

$A Q$

$\sigma C F O$
Closely-held shares at $t$ divided by total shares outstanding at $t$.

Accrual quality, based on Dechow and Dichev (2002) and Biddle et al. (2009), computed as -1 times the standard deviation of the residual (from $t-5$ to $t-1$ ) obtained from regressing a change in working capital on cash from operations in $t+1$, cash from operations in $t$, cash from operations in $t-1$, change in revenue, and property plant and equipment, with all variables scaled by total assets in $t-1$. The model is estimated by country, industry and year, provided the country-industry-year has 10 or more observations.

Standard deviation, computed from year $t-5$ to year $t-1$, of cash flow from operations scaled by total assets in $t-1$. 


\section{Appendix (continued)}

\begin{tabular}{|c|c|}
\hline Variable Name & Variable Definition \\
\hline \multicolumn{2}{|c|}{ Control Variables: } \\
\hline oSale & $\begin{array}{l}\text { Standard deviation, computed from year } t-5 \text { to year } t-1 \text {, of sales scaled by total } \\
\text { assets in } t-1 \text {. }\end{array}$ \\
\hline oInvest & Standard deviation, computed from year $t-5$ to year $t-1$, of Invest. \\
\hline Size & Natural log of total assets in year $t$. \\
\hline OverFirm & $\begin{array}{l}\text { A ranked variable based on the average of a ranked deciles measure of cash } \\
\text { and leverage. Leverage is multiplied by minus one before ranking so that both } \\
\text { variables are increasing in the likelihood of over-investment. }\end{array}$ \\
\hline OpCycle & $\begin{array}{l}\text { Log of net receivables divided by sales, plus inventory divided by cost of } \\
\text { goods sold, all multiplied by } 360 \text {. }\end{array}$ \\
\hline Losses & $\begin{array}{l}\text { Binary variable set equal to } 1 \text { if the net income in year } t \text { and year } t-1 \text { is less } \\
\text { than } 0 \text {, and zero otherwise. }\end{array}$ \\
\hline Foreign & $\begin{array}{l}\text { Binary variable set equal to } 1 \text { if the firm reports foreign sales, foreign assets, or } \\
\text { foreign net income in year } t \text {, and zero otherwise. }\end{array}$ \\
\hline$P P E$ & Property, plant and equipment in year $t$ scaled by total assets in $t-1$. \\
\hline$B M$ & $\begin{array}{l}\text { Book value of equity deflated by the market value of equity. The market value } \\
\text { of equity is computed as the closing stock price times the number of shares } \\
\text { outstanding. }\end{array}$ \\
\hline DivDummy & Binary variable, set equal to 1 if the firm pays a dividend in year $t$. \\
\hline Age & Natural log of current year less the base year (per Datastream/Worldscope). \\
\hline$Q$ & $\begin{array}{l}\text { Tobin's q, computed as the market value of equity plus liabilities, all divided } \\
\text { by total assets. }\end{array}$ \\
\hline CFConst & $\begin{array}{l}\text { Cash flow constraints, computed as negative } 1 \text { multiplied by net cash from } \\
\text { operations scaled by total assets in } t-1 \text {. }\end{array}$ \\
\hline Cash & Cash at $t$ deflated by total assets in $t-1$. \\
\hline
\end{tabular}




\section{References}

Amiram D, Bauer A, Frank MM (2017) Tax avoidance at public corporations driven by shareholder taxes: Evidence from changes in dividend tax policy. Working paper, Columbia University, New York.

Balakrishnan K, Blouin J, Guay W (2017) Tax aggressiveness and corporate transparency. Working paper, University of Pennsylvania, Philadelphia.

Bebchuk L, Cohen A, Ferrell A (2009) What matters in corporate governance? Review of Financial Studies 22 (2): 783-827.

Biddle GC, Hilary G (2006) Accounting quality and firm-level capital investment. The Accounting Review 81 (5): 963-982.

Biddle GC, Hilary G, Verdi RS (2009) How does financial reporting quality relate to investment efficiency? Journal of Accounting and Economics 48 (2-3): 112-131.

Blaylock B (2016) Is tax avoidance associated with economically significant rent extraction among U.S. firms? Contemporary Accounting Research 33 (3): 1013-1043.

Bushman RM, Piotroski JD, Smith AJ (2004) What determines corporate transparency? Journal of Accounting Research 42 (2), 208-252.

Cheng, M, Dhaliwal D, Zhang Y (2013) Does investment efficiency improve after the disclosure of material weaknesses in internal control over financial reporting? Journal of Accounting and Economics 56 (1), 1-18.

DeAngelo H, DeAngelo L, Stulz RM (2006) Dividend policy and the earned/contributed capital mix: a test of the life-cycle theory. Journal of Financial Economics 81 (2): 227-254.

Dechow P., 1994. Accounting earnings and cash flows as measures of firm performance: The role of accounting accruals. Journal of Accounting and Economics 18 (1): 3-42.

Dechow P, Dichev I (2002) The quality of accruals and earnings: The role of accrual estimation errors. The Accounting Review 77 (Supplement): 35-59. 
Dechow P, Kothari SP, Watts RL (1998) The relation between earnings and cash flows. Journal of Accounting and Economics 25 (2): 133-168.

Dechow P, Richardson S, Sloan R (2008) The persistence and pricing of the cash component of earnings. Journal of Accounting Research 46 (3): 537-566.

Desai M, Dharmapala D (2006) Corporate tax avoidance and high powered incentives. Journal of Financial Economics 79 (1): 145-179.

Desai M, Dharmapala D (2009) Corporate tax avoidance and firm value. Review of Economics and Statistics 91 (3): 537-546.

Desai M, Dyck A, Zingales L (2007) Theft and taxes. Journal of Financial Economics 84 (3): 591-623.

De Simone L, Stomberg B (2013) Do investors differentially value tax avoidance by income mobile firms? Working paper, Stanford University, Stanford.

Dhaliwal D, Huang S, Moser W, Pereira R (2011) Corporate tax avoidance and the level and valuation of firm cash holdings. Working paper, University of Arizona, Tucson.

Dittmar A, Mahrt-Smith J, Servaes H (2003) International corporate governance and corporate cash holdings. Journal of Financial and Quantitative Analysis 38 (1): 111-133.

Djankov S, La Porta R, Lopez-de-Silanes F, Shleifer A (2008) The law and economics of self-dealing. Journal of Financial Economics 88 (3): 430-465.

Doidge C, Karolyi A, Stulz R (2007) Why do countries matter so much for corporate governance? Journal of Financial Economics 86 (1):1-39.

Dyreng SD, Hanlon M, Maydew EL (2008) Long-run corporate tax avoidance. The Accounting Review 83 (1): $61-82$.

Edwards A, Kravet T, Wilson R (2016a) Trapped cash and the profitability of foreign acquisitions. Contemporary Accounting Research 33 (1): 44-77.

Edwards A, Schwab C, Shevlin T (2016b) Financial constraints and cash tax savings. The Accounting Review 91 (3): 859-881. 
Fama EF, French KR (2001) Disappearing dividends: Changing firm characteristics or lower propensity to pay? Journal of Financial Economics 60 (1): 3-43.

Fama EF, French KR (2002) Testing trade-off and pecking order predictions about dividends and debt. The Review of Financial Studies 15 (1):1-33.

Gompers P, Ishii J, Metrick A (2003) Corporate governance and equity prices. Quarterly Journal of Economics 118 (1):107-55.

Gow I, Ormazabal G, Taylor DJ (2010) Correcting for cross-sectional and time-series dependence in accounting research. The Accounting Review 85 (2): 483-512.

Guay W, Harford J (2000) The cash-flow permanence and information content of dividend increases versus repurchases. Journal of Financial Economics 57 (3): 385-415.

Grubert H (2003) Intangible income, intercompany transactions, income shifting and the choice of location. National Tax Journal 56 (1): 221-42.

Grubert H, Slemrod J (1998) The effect of taxes on investment and income shifting in Puerto Rico. The Review of Economics and Statistics 80 (3): 365-73.

Guenther DA, Njorobe K, Williams BM (2017) Use of increased operating cash flow by firms that avoid taxes. Working paper, University of Oregon, Eugene.

Hanlon M, Heitzman S (2010) A review of tax research. Journal of Accounting and Economics 50 (2-3): $127-178$.

Hanlon M, Lester R, Verdi RS (2015) The effect of repatriation tax cost on U.S. multinational investment. Journal of Financial Economics 116 (1): 179-196.

Hanlon M, Maydew EL, Saavedra D (2017) The tax man cometh: Does tax uncertainty affect corporate tax holdings? Review of Accounting Studies 22 (3): 1109-1228.

Hanlon M, Slemrod J (2009) What does tax aggressiveness signal? Evidence from stock price reactions to news about tax shelter involvement. Journal of Public Economics 93 (1): 126-141.

Hartford J (1999) Corporate cash reserves and acquisitions. Journal of Finance 54 (6):1968-1997. 
Hubbard RG (1998) Capital-market imperfections and investment. Journal of Economic Literature 36 (1): 193-225.

Hutchens M, Rego S (2015) Does greater tax risk lead to increased firm risk? Working paper, Indiana University, Bloomington.

Jagannathan M, Stephens C, Weisbach M (2000) Financial flexibility and the choice between dividends and stock repurchases. Journal of Financial Economics 57 (3): 355-84.

Jensen M (1986) Aency costs of free cash flows, corporate finance and takeovers. American Economic Review 76, 323-329.

Kerr J (2018) Information opacity, information shocks, and tax avoidance. Contemporary Accounting Research, forthcoming.

La Porta R, Lopez-de-Silanes F, Shleifer A, Vishny RW (2000) Agency problems and dividend policies around the world. The Journal of Finance 55(1): 1-33.

Liu M, Wysocki P (2007) Cross-sectional determinants of information quality proxies and cost of capital measures. Working paper, Massachusetts Institute of Technology, Cambridge.

Modigliani F, Miller M (1958) The cost of capital, corporation finance and the theory of investment. American Economic Review 48 (3): 261-297.

Myers SC (1984) The capital structure puzzle. Journal of Finance 39 (3): 575-592.

Myers SC, Majluf NS (1984) Corporate financing and investment decisions when firms have information the investors do not have. Journal of Financial Economics 13 (2): 187-221.

Nessa M (2017) Repatriation tax costs and U.S. multinational companies' shareholder payouts. The Accounting Review, 92(4): 217-241.

Opler T, Pinkowitz L, Stultz R, Williamson R (1999) The determinants and implications of corporate holdings of liquid assets. Journal of Financial Economics, 52(1): 3-46.

Richardson S (2006) Over-investment of free cash flow. Review of Accounting Studies 11 (2-3):159-189.

Stein J (2003) Agency, information and corporate investment. Constantinides G, Harris M, Stulz R, eds. Handbook of the Economics of Finance (Elseviser Science, Amsterdam), 109-163. 
Table 1. Sample Composition by Country with Descriptive Statistics

\begin{tabular}{|c|c|c|c|c|c|}
\hline & $\mathrm{N}$ & $\%$ & $\begin{array}{c}\text { Mean } \\
\text { CTS }\end{array}$ & $\begin{array}{c}\text { Mean Country } \\
\text { Statutory Tax } \\
\text { Rate } \\
\end{array}$ & Governance \\
\hline AUSTRALIA & 1,558 & $3.38 \%$ & -0.044 & $30.3 \%$ & 94 \\
\hline AUSTRIA & 64 & $0.14 \%$ & 0.032 & $29.0 \%$ & 79 \\
\hline BELGIUM & 79 & $0.17 \%$ & 0.018 & $36.1 \%$ & 76 \\
\hline$C A N A D A$ & 1,360 & $2.95 \%$ & 0.072 & $33.6 \%$ & 66 \\
\hline CHILE & 306 & $0.66 \%$ & -0.027 & $16.6 \%$ & 76 \\
\hline CZECH REPUBLIC & 15 & $0.03 \%$ & 0.039 & $30.3 \%$ & - \\
\hline DENMARK & 290 & $0.63 \%$ & -0.031 & $28.5 \%$ & 77 \\
\hline FINLAND & 268 & $0.58 \%$ & -0.088 & $27.1 \%$ & 89 \\
\hline FRANCE & 1,149 & $2.49 \%$ & 0.058 & $35.4 \%$ & 66 \\
\hline GERMANY & 1,198 & $2.60 \%$ & 0.020 & $37.1 \%$ & 73 \\
\hline GREECE & 95 & $0.21 \%$ & -0.319 & $26.0 \%$ & 66 \\
\hline IRELAND & 100 & $0.22 \%$ & -0.173 & $15.2 \%$ & 92 \\
\hline ISRAEL & 99 & $0.21 \%$ & 0.001 & $29.5 \%$ & 66 \\
\hline ITALY & 302 & $0.65 \%$ & -0.182 & $32.1 \%$ & 66 \\
\hline$J A P A N$ & 10,837 & $23.50 \%$ & -0.095 & $39.8 \%$ & 83 \\
\hline MEXICO & 13 & $0.03 \%$ & 0.043 & $30.0 \%$ & 66 \\
\hline NETHERLANDS & 8 & $0.02 \%$ & -0.005 & $31.3 \%$ & 86 \\
\hline NEW ZEALAND & 286 & $0.62 \%$ & 0.005 & $31.6 \%$ & 95 \\
\hline NORWAY & 66 & $0.14 \%$ & 0.012 & $28.0 \%$ & 90 \\
\hline POLAND & 299 & $0.65 \%$ & -0.087 & $19.1 \%$ & - \\
\hline PORTUGAL & 152 & $0.33 \%$ & 0.014 & $29.8 \%$ & 70 \\
\hline SOUTH KOREA & 62 & $0.13 \%$ & 0.065 & $27.0 \%$ & 78 \\
\hline SPAIN & 153 & $0.33 \%$ & 0.046 & $33.4 \%$ & 80 \\
\hline SWEDEN & 720 & $1.56 \%$ & -0.034 & $27.6 \%$ & 97 \\
\hline SWITZERLAND & 697 & $1.51 \%$ & -0.070 & $22.9 \%$ & 87 \\
\hline TURKEY & 266 & $0.58 \%$ & -0.037 & $22.6 \%$ & 67 \\
\hline UNITED KINGDOM & 6,064 & $13.15 \%$ & -0.015 & $29.5 \%$ & 95 \\
\hline \multirow[t]{2}{*}{ UNITED STATES } & 19,615 & $42.53 \%$ & 0.089 & $39.3 \%$ & 76 \\
\hline & 46,121 & $100 \%$ & & & \\
\hline
\end{tabular}

Notes. This table presents sample composition by country along with a summary of the means of pertinent descriptive statistics. Variable definitions are available in the Appendix. The descriptive statistics are based upon data for the years 1993 through 2011 and with data sufficient to estimate the empirical model for investment. CSTR is the average enacted corporate statutory rate over the sample period, and reflects a blending of federal and local rates. This table includes firms with both multinational and domestic operations ("full sample"). 
Table 2. Firm-Level Descriptive Statistics

\begin{tabular}{|c|c|c|c|c|c|c|}
\hline \multicolumn{7}{|c|}{ Panel A: Full sample } \\
\hline Variable & $\mathbf{N}$ & Mean & Std Dev & Min & Median & Max \\
\hline ChgCash & 55,092 & 0.028 & 0.150 & -0.212 & 0.006 & 0.486 \\
\hline Cash & 55,093 & 0.172 & 0.237 & 0.000 & 0.103 & 0.919 \\
\hline Invest & 55,373 & 0.098 & 0.139 & -0.103 & 0.064 & 0.671 \\
\hline absInvestEff & 43,216 & 0.064 & 0.752 & 0.001 & 0.041 & 0.473 \\
\hline CashDiv & 55,221 & 0.016 & 0.025 & 0.000 & 0.008 & 0.150 \\
\hline CTS & 46,121 & 0.012 & 0.463 & -3.013 & 0.081 & 0.656 \\
\hline CloseShares & 55,373 & 0.383 & 0.351 & 0.001 & 0.323 & 2.047 \\
\hline$A Q$ & 55,373 & -0.400 & 0.985 & -6.537 & -0.097 & -0.010 \\
\hline$\sigma C F O$ & 55,373 & 0.058 & 0.148 & 0.005 & 0.032 & 0.391 \\
\hline oSale & 55,373 & 0.268 & 0.339 & 0.021 & 0.174 & 1.715 \\
\hline oInvest & 55,373 & 0.083 & 0.149 & 0.003 & 0.040 & 0.673 \\
\hline Size & 55,373 & 20.28 & 1.988 & 15.71 & 20.22 & 25.07 \\
\hline OpCycle & 55,373 & -414.4 & 253.8 & -1214 & -388.3 & 167.3 \\
\hline Losses & 55,373 & 0.089 & 0.285 & 0.000 & 0.000 & 1.000 \\
\hline Foreign & 55,373 & 0.573 & 0.495 & 0.000 & 1.000 & 1.000 \\
\hline PPE/TA & 55,373 & 0.663 & 0.470 & 0.028 & 0.579 & 2.152 \\
\hline DivDummy & 55,373 & 0.708 & 0.455 & 0.000 & 1.000 & 1.000 \\
\hline$B M$ & 55,373 & 0.891 & 1.224 & -0.060 & 0.612 & 6.300 \\
\hline Age & 55,373 & 2.724 & 0.662 & 1.099 & 2.773 & 3.689 \\
\hline$Q$ & 55,373 & 1.618 & 1.499 & 0.517 & 1.253 & 6.638 \\
\hline CFConst & 54,964 & -0.109 & 0.112 & -0.459 & -0.097 & 0.125 \\
\hline NWC & 55,373 & 0.226 & 0.297 & -0.298 & 0.192 & 0.988 \\
\hline Lev & 55,373 & 0.578 & 0.405 & 0.065 & 0.551 & 1.679 \\
\hline CapEx & 55,373 & 0.059 & 0.070 & 0.001 & 0.040 & 0.342 \\
\hline
\end{tabular}

Notes. This table presents descriptive statistics for all variables used in regression analyses. Variable definitions follow those as detailed in the Appendix. The descriptive statistics are based upon data for the years 1993 through 2011. The "full-sample" is comprised of firms that have multinational and domestic operations. 
Table 2. Firm-Level Descriptive Statistics

\begin{tabular}{|c|c|c|c|c|c|c|}
\hline \multirow[b]{2}{*}{ Variable } & \multirow[b]{2}{*}{$\mathrm{N}$} & \multicolumn{4}{|c|}{ Panel B: Domestic-only Sample } & \multirow[b]{2}{*}{ Max } \\
\hline & & Mean & Std Dev & Min & Median & \\
\hline ChgCash & 37,726 & 0.028 & 0.155 & -0.213 & 0.005 & 0.524 \\
\hline Cash & 37,726 & 0.168 & 0.237 & 0.000 & 0.096 & 0.942 \\
\hline Invest & 37,908 & 0.094 & 0.142 & -0.108 & 0.058 & 0.685 \\
\hline absInvestEff & 33,043 & 0.063 & 0.075 & 0.001 & 0.040 & 0.473 \\
\hline CashDiv & 37,789 & 0.016 & 0.026 & 0.000 & 0.008 & 0.158 \\
\hline CTS & 30,190 & 0.015 & 0.459 & -2.866 & 0.078 & 0.656 \\
\hline CloseShares & 37,908 & 0.416 & 0.362 & 0.001 & 0.363 & 2.406 \\
\hline$A Q$ & 37,908 & -0.395 & 0.996 & -6.537 & -0.095 & -0.009 \\
\hline$\sigma C F O$ & 37,908 & 0.062 & 0.161 & 0.005 & 0.033 & 0.444 \\
\hline oSale & 37,908 & 0.286 & 0.366 & 0.020 & 0.183 & 1.921 \\
\hline oInvest & 37,908 & 0.084 & 0.155 & 0.002 & 0.040 & 0.704 \\
\hline Size & 37,908 & 19.991 & 1.966 & 15.515 & 19.929 & 24.914 \\
\hline OpCycle & 37,908 & -432.6 & 271.4 & -1276.5 & -405.2 & 199.8 \\
\hline Losses & 37,908 & 0.090 & 0.286 & 0.000 & 0.000 & 1.000 \\
\hline Foreign & 37,908 & 0.377 & 0.485 & 0.000 & 0.000 & 1.000 \\
\hline PPE/TA & 37,908 & 0.682 & 0.493 & 0.024 & 0.596 & 2.291 \\
\hline DivDummy & 37,908 & 0.703 & 0.457 & 0.000 & 1.000 & 1.000 \\
\hline$B M$ & 37,908 & 0.967 & 1.329 & -0.049 & 0.658 & 7.613 \\
\hline Age & 37,908 & 2.673 & 0.653 & 1.099 & 2.708 & 3.689 \\
\hline$Q$ & 37,908 & 1.564 & 1.536 & 0.503 & 1.204 & 6.530 \\
\hline CFConst & 37,505 & -0.106 & 0.120 & -0.478 & -0.094 & 0.142 \\
\hline$N W C$ & 37,908 & 0.220 & 0.310 & -0.314 & 0.181 & 1.016 \\
\hline Lev & 37,908 & 0.582 & 0.427 & 0.059 & 0.552 & 1.726 \\
\hline CapEx & 37,908 & 0.061 & 0.075 & 0.001 & 0.040 & 0.372 \\
\hline
\end{tabular}

Notes. This table presents descriptive statistics for all variables used in regression analyses. Variable definitions follow those as detailed in the Appendix. The descriptive statistics are based upon data for the years 1993 through 2011. The "domestic-only sample" is comprised of firms with only domestic operations. 
Table 3. Correlation Matrix

\begin{tabular}{|c|c|c|c|c|c|c|c|c|c|c|c|c|c|c|c|c|c|c|c|c|c|c|c|c|}
\hline Variable & & (1) & (2) & (3) & (4) & (5) & (6) & (7) & (8) & (9) & (10) & (11) & (12) & (13) & (14) & (15) & (16) & (17) & (18) & (19) & $(20)$ & (21) & (22) & (23) \\
\hline$\overline{C h g C a s h}$ & (1) & $\begin{array}{ll}1 \\
\end{array}$ & $0.641^{*}$ & $0.0137^{*}$ & $0.0376^{*}$ & $-0.0728^{*}$ & $0.0787^{*}$ & $-0.0200^{*}$ & $-0.0449^{*}$ & $0.156^{*}$ & $0.106^{*}$ & $0.0582^{*}$ & $-0.0596^{*}$ & -0.000820 & $-0.0172^{*}$ & & $-0.0367 *$ & $-0.0434^{*}$ & $-0.0760^{*}$ & $0.159^{*}$ & $-0.291^{*}$ & $0.382^{*}$ & $0.0659^{*}$ & 0.0124 \\
\hline Cash/TA & (2) & 0.6 & 1 & $0.0605^{*}$ & $0.0825^{*}$ & $0.0443^{*}$ & $0.0393 *$ & 0.0127 & $-0.0586^{*}$ & $0.233^{*}$ & $0.133^{*}$ & 0.00146 & $-0.211^{*}$ & 0.000877 & $-0.0181^{*}$ & & $-0.255^{*}$ & $-0.0844 *$ & $-0.170^{*}$ & $0.286^{*}$ & $-0.277^{*}$ & $0.592 *$ & $-0.151^{*}$ & $-0.0691 *$ \\
\hline Invest & (3) & $0.0474 *$ & $0.0938^{*}$ & 1 & $0.658^{*}$ & $-0.0414^{*}$ & 0.0564* & $-0.101^{*}$ & $-0.140^{*}$ & $0.110^{*}$ & $0.0587^{*}$ & $0.352^{*}$ & -0.0104 & $-0.0187 *$ & $-0.0164^{*}$ & & $0.188^{*}$ & $-0.117^{*}$ & $-0.113^{*}$ & $0.171^{*}$ & $-0.299 *$ & 0.00693 & $0.318^{*}$ & $0.450^{*}$ \\
\hline absInvestEff & (4) & $0.0311^{*}$ & $0.0829 *$ & $0.652 *$ & & -0.00128 & $0.0405^{*}$ & $-0.0645^{*}$ & $-0.142^{*}$ & $0.112^{*}$ & $0.127^{*}$ & $0.327 *$ & $-0.118^{*}$ & $-0.0233^{*}$ & 0.00193 & & 0.0110 & $-0.0833^{*}$ & $-0.113^{*}$ & $0.124^{*}$ & $-0.179 *$ & $0.0512^{*}$ & $0.236^{*}$ & $0.256 *$ \\
\hline DivPay & $\begin{array}{l}\text { (5) } \\
\text { (5) }\end{array}$ & $\begin{array}{l}0.00767 * \\
-0\end{array}$ & -0.00602 & $\begin{array}{l}-0.00401 * \\
-\end{array}$ & -0.00235 & $-0.001<0$ & $-0.0212 *$ & $0.0522^{*}$ & $0.0395 *$ & $0.0180^{*}$ & $\begin{array}{l}0.00637 \\
-0.127\end{array}$ & $-0.0309 *$ & $\begin{array}{l}-0.0679 * \\
-0.10\end{array}$ & $\begin{array}{l}-0.0335 * \\
-\end{array}$ & $\begin{array}{l}-0.0351^{*} \\
-\end{array}$ & & 0754 & $\begin{array}{l}-0.0051^{*} \\
-0.12 x^{2}\end{array}$ & -0.00642 & $0.208^{*}$ & $-0.224^{*}$ & 0.00753 & $\begin{array}{l}-0.0897 * \\
-20\end{array}$ & $\begin{array}{l}-0.00231 \\
-\end{array}$ \\
\hline $\begin{array}{l}\text { CTS } \\
\text { CTS }\end{array}$ & $\begin{array}{l}\text { (J) } \\
\text { (6) }\end{array}$ & $0.0745^{*}$ & $\begin{array}{l}0.0516^{*} \\
0\end{array}$ & $0.0448^{*}$ & $\begin{array}{l}-0.002030 \\
0.0368^{*}\end{array}$ & $-0.0262 *$ & $-0.0211^{-1}$ & $\begin{array}{l}-0.05066^{*}\end{array}$ & $\begin{array}{l}-0.0684^{*} \\
-\end{array}$ & $0.0294^{*}$ & $\begin{array}{l}-0.0073 / \\
0.00732\end{array}$ & $\begin{array}{l}-0.030124 \\
0.012\end{array}$ & $\begin{array}{l}-0.0107 \\
-0.019\end{array}$ & $\begin{array}{l}-0.0218^{*} \\
-0.00\end{array}$ & $-0.141^{*}$ & & 54 & $\begin{array}{l}-0.121 \\
-0.0777 *\end{array}$ & $\begin{array}{l}-0.00720 \\
-0.00720\end{array}$ & $\begin{array}{l}0.0964^{*} \\
0\end{array}$ & $\begin{array}{l}-0.24 * \\
-0.167 *\end{array}$ & $.0515^{*}$ & $\begin{array}{l}-0.0037 \\
0.0224^{*}\end{array}$ & $\begin{array}{l}-0.0592 * \\
0.052\end{array}$ \\
\hline CloseShares & $\begin{array}{l}\text { (1) } \\
\text { (7) }\end{array}$ & $\begin{array}{l}-0.0249 * \\
-\end{array}$ & $\begin{array}{l}-0.01788^{*} \\
-\end{array}$ & $\begin{array}{l}0.0440 \\
-0.0972 *\end{array}$ & $\begin{array}{l}0.0300 \\
-0.0596 *\end{array}$ & $\begin{array}{l}=0.0202 \\
0.0358^{*}\end{array}$ & $\begin{array}{l}-0.0413 * \\
-\end{array}$ & -0.0500 & $\begin{array}{l}-0.0800^{*} \\
0.080^{2}\end{array}$ & $\begin{array}{l}0.0294 \\
-0.0128\end{array}$ & 165 & $6639 *$ & -0 & 9* & 0.0 & & & $0.466^{*}$ & -0. & $\begin{array}{l}-0.154^{*} \\
-0.0\end{array}$ & $0.0556^{*}$ & $49 *$ & $\begin{array}{l}-0.0436 * \\
-0.043\end{array}$ & $\begin{array}{l}-0.04177^{2} \\
-\end{array}$ \\
\hline res & (8) & $\begin{array}{l}-0.0496 \\
-0.0639 * \\
-\end{array}$ & $\begin{array}{l}-0.0760^{*} \\
-0.0\end{array}$ & $\begin{array}{l}-0.0116^{*} \\
- \\
-\end{array}$ & $\begin{array}{l}-0.00950^{*} \\
-0.117^{2}\end{array}$ & $0.0438^{*}$ & $\begin{array}{l}-0.0573^{*} \\
-0.041\end{array}$ & $0.0700^{*}$ & 0.0826 & $\begin{array}{l}-0.0128 \\
-0.135 *\end{array}$ & $5^{*}$ & $28^{*}$ & & & 0.8 & & & & & $\begin{array}{l}-0.154^{*} \\
-0.156^{-1}\end{array}$ & $\begin{array}{l}0.05374^{*} \\
0\end{array}$ & $60^{*}$ & $\begin{array}{l}-0.0450^{\circ} \\
-0.00370\end{array}$ & $\begin{array}{l}-0.0118^{*} \\
-0.04\end{array}$ \\
\hline CFO & $\begin{array}{l}\text { (8) } \\
\text { (9) }\end{array}$ & $\begin{array}{l}-0.1833^{*} \\
0.04\end{array}$ & $\begin{array}{l}-0.218^{*} \\
0.07\end{array}$ & $\begin{array}{l}-0.1163^{*} \\
0.120\end{array}$ & $0.102^{*}$ & $\begin{array}{l}-0.0090942 * \\
-0.04\end{array}$ & $\begin{array}{l}-0.0414^{*} \\
0\end{array}$ & -0.00800 & $\begin{array}{l}1 \\
-0.126^{*}\end{array}$ & & $0.481^{*}$ & $3^{*}$ & -0.1 & $0^{*}$ & $\begin{array}{l}0.00461 \\
0.006\end{array}$ & & $\begin{array}{l}-0.000359 \\
-0.0814^{*}\end{array}$ & $\begin{array}{l}-0.0611^{*} \\
-\end{array}$ & $\begin{array}{l}0.0 \\
-0 .\end{array}$ & $\begin{array}{l}0.166^{*} \\
0.0150\end{array}$ & $\begin{array}{l}0.1 / 40^{*} \\
-0.18\end{array}$ & $100^{\prime \prime}$ & $\begin{array}{l}-0.00370 \\
-0.00932\end{array}$ & $0.0531 *$ \\
\hline Sale & $\begin{array}{l}\text { (10) } \\
\text { (10) }\end{array}$ & $0.128^{*}$ & $\begin{array}{l}0.210 \\
0.132 *\end{array}$ & $0.0669^{*}$ & $20^{*}$ & $\begin{array}{l}-0.00942 \\
-0.0269 *\end{array}$ & $\begin{array}{l}0.0180^{*} \\
0.04\end{array}$ & $0.0184^{*}$ & $\begin{array}{l}-0.1100 \\
-0.108^{*}\end{array}$ & $0.444 *$ & & $0.302^{*}$ & $\begin{array}{l}-0.1 \\
-0.2\end{array}$ & t. & 0.0132 & & $\begin{array}{l}-0.0014 \\
-0.196^{*}\end{array}$ & $\begin{array}{l}-0.0011 \\
-0.0499 *\end{array}$ & $\begin{array}{l}-0 . \\
-0 . \\
-0 .\end{array}$ & $\begin{array}{l}0.121^{*} \\
0.0\end{array}$ & $\begin{array}{l}-0.100 \\
-0.106^{*}\end{array}$ & $0.128^{*}$ & $\begin{array}{l}-0.00922 \\
0.124^{*}\end{array}$ & $\begin{array}{l}-0.02033^{*} \\
-\end{array}$ \\
\hline est & (11) & $0.0854 *$ & $\begin{array}{l}0.0460^{*} \\
0.13\end{array}$ & 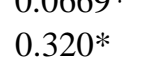 & $0.1322^{*}$ & $25 *$ & $0.0107 *$ & $22^{4 *}$ & $5 *$ & 0.3 & 0. & & $-0.6 \quad$ & & 0.8 & & & $\begin{array}{l}-0.0499 * \\
-0.0392 *\end{array}$ & & $5 *$ & $\begin{array}{l}-0.10958^{*} \\
-0.09\end{array}$ & $\begin{array}{l}0.0450 * \\
-0.04\end{array}$ & $\begin{array}{l}0.126^{*} \\
0.17\end{array}$ & $0.116^{*}$ \\
\hline & & & $-0.151^{*}$ & & & & $26^{*}$ & & & & & & & $-0.0462^{*}$ & & & & & & & & & & 0* \\
\hline & & & & & & & & & & & & & & & 0.0 & & & & & & & & & $91 *$ \\
\hline & & & 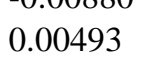 & & & & & & & & & & 4* & & & & 0189* & $0140^{*}$ & 00688 & $.0243^{*}$ & $561^{*}$ & 0318* & $0342^{*}$ & $0.0281^{*}$ \\
\hline & & & & & & & & & & & & & & & & & & & & & & & & \\
\hline & & & & & & & & & & & & & & & & & & & & & & & & \\
\hline & & & & & & & & & & & & & & & & & & & & & & & & \\
\hline & & & & & & & & & & & & & & & & & & & & & & & & \\
\hline & & & & & & & & & & & & & & & & & & & & & & & & \\
\hline & & & & & & & & & & & & & & & & & & & & & & & & \\
\hline & & & & & & & & & & & & & & & & & & & & & & & & \\
\hline & (22) & & & & & & & & & & & & & & & & & & & & & & & \\
\hline IDE & (23) & $0.0295^{*}$ & $\begin{array}{l}-0.0454 * \\
-0.040\end{array}$ & $0.441^{*}$ & $234 *$ & $110^{*}$ & $06^{2} *$ & $291 *$ & $0.104 *$ & $0.0640^{*}$ & $64^{*}$ & 4* & $0.0493^{*}$ & $-0.166^{*}$ & $92 *$ & & $0^{*}$ & 112* & 0502* & $11^{*}$ & $5 *$ & $1.143^{*}$ & $0.149 *$ & \\
\hline
\end{tabular}

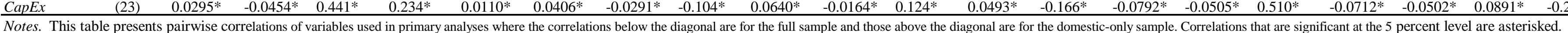


Table 4. Cash Tax Savings and Level of Cash Holdings

\begin{tabular}{|c|c|c|c|c|c|c|}
\hline & \multicolumn{3}{|c|}{ Full sample } & \multicolumn{3}{|c|}{ Domestic-only Sample } \\
\hline & (1) & $(2)$ & (3) & (4) & (5) & (6) \\
\hline & $\mathrm{Cash}_{t}$ & Cash $_{t+1}$ & Cash $_{t+2}$ & $\mathrm{Cash}_{t}$ & Cash $_{t+1}$ & Cash $_{t+2}$ \\
\hline CTS & $\begin{array}{c}0.007^{* * *} \\
{[0.002]}\end{array}$ & $\begin{array}{c}0.005^{* * *} \\
{[0.002]}\end{array}$ & $\begin{array}{c}-0.000 \\
{[0.002]}\end{array}$ & $\begin{array}{c}0.007 * * * \\
{[0.002]}\end{array}$ & $\begin{array}{c}0.004^{*} \\
{[0.002]}\end{array}$ & $\begin{array}{c}-0.001 \\
{[0.002]}\end{array}$ \\
\hline CloseShares & $\begin{array}{c}0.010^{* * *} \\
{[0.004]}\end{array}$ & $\begin{array}{c}0.020 * * * \\
{[0.003]}\end{array}$ & $\begin{array}{c}0.023^{* * *} \\
{[0.003]}\end{array}$ & $\begin{array}{l}0.009 * * \\
{[0.004]}\end{array}$ & $\begin{array}{c}0.019 * * * \\
{[0.004]}\end{array}$ & $\begin{array}{c}0.023^{* * *} \\
{[0.004]}\end{array}$ \\
\hline NWC & $\begin{array}{c}0.565^{* * *} \\
{[0.015]}\end{array}$ & $\begin{array}{c}0.235 * * * \\
{[0.011]}\end{array}$ & $\begin{array}{c}0.197 * * * \\
{[0.011]}\end{array}$ & $\begin{array}{c}0.564 * * * \\
{[0.016]}\end{array}$ & $\begin{array}{c}0.232^{* * *} \\
{[0.012]}\end{array}$ & $\begin{array}{c}0.196 * * * \\
{[0.011]}\end{array}$ \\
\hline Lev & $\begin{array}{c}0.112^{* * *} \\
{[0.011]}\end{array}$ & $\begin{array}{c}-0.041^{* * *} \\
{[0.005]}\end{array}$ & $\begin{array}{c}-0.041^{* * *} \\
{[0.005]}\end{array}$ & $\begin{array}{c}0.109 * * * \\
{[0.013]}\end{array}$ & $\begin{array}{c}-0.038 * * * \\
{[0.006]}\end{array}$ & $\begin{array}{c}-0.039 * * * \\
{[0.006]}\end{array}$ \\
\hline CapEx & $\begin{array}{c}0.155^{* * *} \\
{[0.014]}\end{array}$ & $\begin{array}{c}0.018 \\
{[0.013]}\end{array}$ & $\begin{array}{c}0.009 \\
{[0.014]}\end{array}$ & $\begin{array}{c}0.155^{* * *} \\
{[0.015]}\end{array}$ & $\begin{array}{c}0.021 \\
{[0.017]}\end{array}$ & $\begin{array}{c}0.012 \\
{[0.015]}\end{array}$ \\
\hline$R D$ & $\begin{array}{c}0.709 * * * \\
{[0.044]}\end{array}$ & $\begin{array}{c}0.662 * * * \\
{[0.048]}\end{array}$ & $\begin{array}{c}0.667 * * * \\
{[0.054]}\end{array}$ & $\begin{array}{c}0.747^{* * *} \\
{[0.050]}\end{array}$ & $\begin{array}{c}0.677 * * * \\
{[0.054]}\end{array}$ & $\begin{array}{c}0.683^{* * *} \\
{[0.059]}\end{array}$ \\
\hline Size & $\begin{array}{c}0.004^{* * *} \\
{[0.001]}\end{array}$ & $\begin{array}{c}-0.004^{* * *} \\
{[0.001]}\end{array}$ & $\begin{array}{c}-0.005^{* * *} \\
{[0.001]}\end{array}$ & $\begin{array}{c}0.002 \\
{[0.001]}\end{array}$ & $\begin{array}{c}-0.007 * * * \\
{[0.001]}\end{array}$ & $\begin{array}{c}-0.007^{* * *} \\
{[0.001]}\end{array}$ \\
\hline OpCycle & $\begin{array}{c}-0.000^{* * *} \\
{[0.000]}\end{array}$ & $\begin{array}{c}-0.000 * * * \\
{[0.000]}\end{array}$ & $\begin{array}{c}-0.000 * * * \\
{[0.000]}\end{array}$ & $\begin{array}{c}-0.000 * * * \\
{[0.000]}\end{array}$ & $\begin{array}{c}-0.000 * * * \\
{[0.000]}\end{array}$ & $\begin{array}{c}-0.000 * * * \\
{[0.000]}\end{array}$ \\
\hline Losses & $\begin{array}{c}0.020 * * * \\
{[0.005]}\end{array}$ & $\begin{array}{c}0.006 \\
{[0.004]}\end{array}$ & $\begin{array}{c}0.012 * * * \\
{[0.003]}\end{array}$ & $\begin{array}{c}0.023^{* * *} \\
{[0.005]}\end{array}$ & $\begin{array}{c}0.006 \\
{[0.005]}\end{array}$ & $\begin{array}{c}0.014^{* * *} \\
{[0.004]}\end{array}$ \\
\hline Foreign & $\begin{array}{c}0.008^{* * *} \\
{[0.003]}\end{array}$ & $\begin{array}{c}0.011^{* * *} \\
{[0.002]}\end{array}$ & $\begin{array}{c}0.012 * * * \\
{[0.002]}\end{array}$ & & & \\
\hline$P P E$ & $\begin{array}{c}-0.038 * * * \\
{[0.005]}\end{array}$ & $\begin{array}{c}-0.051^{* * *} \\
{[0.003]}\end{array}$ & $\begin{array}{c}-0.049 * * * \\
{[0.003]}\end{array}$ & $\begin{array}{c}-0.034 * * * \\
{[0.005]}\end{array}$ & $\begin{array}{c}-0.050 * * * \\
{[0.003]}\end{array}$ & $\begin{array}{c}-0.048 * * * \\
{[0.004]}\end{array}$ \\
\hline$B M$ & $\begin{array}{c}-0.002 \\
{[0.001]}\end{array}$ & $\begin{array}{c}-0.010^{* * *} \\
{[0.001]}\end{array}$ & $\begin{array}{c}-0.008^{* * *} \\
{[0.001]}\end{array}$ & $\begin{array}{c}-0.001 \\
{[0.001]}\end{array}$ & $\begin{array}{c}-0.009 * * * \\
{[0.001]}\end{array}$ & $\begin{array}{c}-0.007^{* * *} \\
{[0.001]}\end{array}$ \\
\hline DivDummy & $\begin{array}{c}-0.016^{* * *} \\
{[0.004]}\end{array}$ & $\begin{array}{c}-0.018 * * * \\
{[0.003]}\end{array}$ & $\begin{array}{c}-0.018 * * * \\
{[0.003]}\end{array}$ & $\begin{array}{c}-0.013 * * * \\
{[0.004]}\end{array}$ & $\begin{array}{c}-0.015^{* * *} \\
{[0.003]}\end{array}$ & $\begin{array}{c}-0.015^{* * *} \\
{[0.004]}\end{array}$ \\
\hline Age & $\begin{array}{c}-0.003 \\
{[0.002]}\end{array}$ & $\begin{array}{c}-0.004^{* * *} \\
{[0.002]}\end{array}$ & $\begin{array}{c}-0.002 \\
{[0.002]}\end{array}$ & $\begin{array}{c}-0.003 \\
{[0.002]}\end{array}$ & $\begin{array}{c}-0.004^{* *} \\
{[0.002]}\end{array}$ & $\begin{array}{c}-0.001 \\
{[0.002]}\end{array}$ \\
\hline$Q$ & $\begin{array}{c}0.016^{* * *} \\
{[0.002]}\end{array}$ & $\begin{array}{c}0.011^{* * *} \\
{[0.001]}\end{array}$ & $\begin{array}{c}0.011^{* * *} \\
{[0.001]}\end{array}$ & $\begin{array}{c}0.017 * * * \\
{[0.002]}\end{array}$ & $\begin{array}{c}0.010 * * * \\
{[0.001]}\end{array}$ & $\begin{array}{c}0.010^{* * *} \\
{[0.001]}\end{array}$ \\
\hline Observations & 91187 & 81833 & 67505 & 62867 & 55724 & 45648 \\
\hline Adjusted R-squared & 0.543 & 0.383 & 0.355 & 0.551 & 0.368 & 0.340 \\
\hline Fixed Effects & C I Y & C I Y & C I Y & C I Y & C I Y & C I Y \\
\hline
\end{tabular}


Table 5. Uses of Cash Tax Savings

\begin{tabular}{|c|c|c|}
\hline & $\begin{array}{c}\text { Panel A: Investment } \\
\text { Full sample } \\
\text { (1) } \\
\text { Invest }\end{array}$ & $\begin{array}{c}\text { Domestic-only Sample } \\
(2) \\
\text { Invest } \\
\end{array}$ \\
\hline CTS & $\begin{array}{c}0.006^{* * *} \\
{[0.002]}\end{array}$ & $\begin{array}{c}0.007^{* * *} \\
{[0.001]}\end{array}$ \\
\hline CloseShares & $\begin{array}{c}-0.008^{* *} \\
{[0.003]}\end{array}$ & $\begin{array}{c}-0.008 * * \\
{[0.003]}\end{array}$ \\
\hline$A Q$ & $\begin{array}{c}-0.004^{* * *} \\
{[0.001]}\end{array}$ & $\begin{array}{c}-0.005^{* * *} \\
{[0.002]}\end{array}$ \\
\hline$\sigma C F O$ & $\begin{array}{l}0.030 * * \\
{[0.013]}\end{array}$ & $\begin{array}{c}0.035^{* *} \\
{[0.017]}\end{array}$ \\
\hline oSale & $\begin{array}{c}-0.011^{* * *} \\
{[0.003]}\end{array}$ & $\begin{array}{c}-0.013^{* * *} \\
{[0.004]}\end{array}$ \\
\hline oInvest & $\begin{array}{c}0.057 * * * \\
{[0.014]}\end{array}$ & $\begin{array}{c}0.061^{* * *} \\
{[0.015]}\end{array}$ \\
\hline Size & $\begin{array}{c}0.001^{*} \\
{[0.001]}\end{array}$ & $\begin{array}{c}0.003^{* * *} \\
{[0.001]}\end{array}$ \\
\hline Overfirm & $\begin{array}{c}0.006 * * * \\
{[0.000]}\end{array}$ & $\begin{array}{c}0.005^{* * * *} \\
{[0.001]}\end{array}$ \\
\hline OpCycle & $\begin{array}{c}0.000^{* * *} \\
{[0.000]}\end{array}$ & $\begin{array}{c}0.000^{* * *} \\
{[0.000]}\end{array}$ \\
\hline Losses & $\begin{array}{c}-0.009 * * \\
{[0.004]}\end{array}$ & $\begin{array}{c}-0.010^{* *} \\
{[0.004]}\end{array}$ \\
\hline$P P E$ & $\begin{array}{c}0.005^{* * *} \\
{[0.002]}\end{array}$ & $\begin{array}{c}0.050 * * * \\
{[0.003]}\end{array}$ \\
\hline$B M$ & $\begin{array}{c}0.055^{* * *} \\
{[0.003]}\end{array}$ & $\begin{array}{c}-0.003^{* * *} \\
{[0.001]}\end{array}$ \\
\hline DivDummy & $\begin{array}{c}-0.003^{* * *} \\
{[0.001]}\end{array}$ & $\begin{array}{c}-0.016 * * * \\
{[0.003]}\end{array}$ \\
\hline Age & $\begin{array}{c}-0.019 * * * \\
{[0.003]}\end{array}$ & $\begin{array}{c}-0.015^{* * *} \\
{[0.002]}\end{array}$ \\
\hline$Q$ & $\begin{array}{c}0.013^{* * *} \\
{[0.002]}\end{array}$ & $\begin{array}{c}0.012^{* * *} \\
{[0.002]}\end{array}$ \\
\hline $\begin{array}{l}\text { Observations } \\
\text { Adjusted R-squared } \\
\text { Fixed Effects } \\
\end{array}$ & $\begin{array}{l}45227 \\
0.155 \\
\text { C I Y } \\
\end{array}$ & $\begin{array}{l}29510 \\
0.153 \\
\text { C I Y } \\
\end{array}$ \\
\hline \multicolumn{3}{|c|}{$\begin{array}{l}\text { Notes: This table presents OLS and 2SLS regression estimations. All variables are as defined } \\
\text { in the Appendix. Robust standard errors clustered at the firm and year levels are reported in } \\
\text { brackets below the coefficients. Additionally, country, industry, and year fixed effects are } \\
\text { included in the models as indicated, though the coefficients are not reported. Significance } \\
\text { levels are based upon two-sided t-tests and are indicated as follows: }{ }^{*}<0.1,{ }^{* *} \mathrm{p}<0.05,{ }^{* * *} \\
\mathrm{p}<0.01 \text {. The "full-sample" is comprised of firms that have multinational and domestic } \\
\text { operations. }\end{array}$} \\
\hline
\end{tabular}


Panel B: Dividends

\begin{tabular}{|c|c|c|c|c|c|c|c|c|}
\hline \multicolumn{9}{|c|}{ Panel B: Dividends } \\
\hline & \multicolumn{4}{|c|}{ Full sample } & \multicolumn{4}{|c|}{ Domestic-only Sample } \\
\hline & (1) & (2) & (3) & (4) & (5) & (6) & (7) & (8) \\
\hline & OLS & OLS & Logit & Probit & OLS & OLS & Logit & Probit \\
\hline & CashDiv & Payout & DivDummy & DivDummy & CashDiv & Payout & DivDummy & DivDummy \\
\hline \multirow[t]{2}{*}{ CTS } & $-0.002^{* * *}$ & $-0.003^{* * *}$ & $-0.463^{* * *}$ & $-0.236 * * *$ & $-0.002^{* * *}$ & $-0.004 * * *$ & $-0.467 * * *$ & $-0.238 * * *$ \\
\hline & {$[0.000]$} & {$[0.001]$} & {$[0.047]$} & {$[0.022]$} & {$[0.000]$} & {$[0.001]$} & {$[0.059]$} & {$[0.027]$} \\
\hline \multirow[t]{2}{*}{ CloseShares } & $0.005^{* * *}$ & $0.010 * * *$ & $1.343^{* * *}$ & $0.711^{* * *}$ & $0.005^{* * *}$ & $0.010^{* * *}$ & $1.154^{* * *}$ & $0.627 * * *$ \\
\hline & {$[0.001]$} & {$[0.001]$} & {$[0.111]$} & {$[0.059]$} & {$[0.001]$} & {$[0.001]$} & {$[0.116]$} & {$[0.062]$} \\
\hline \multirow{2}{*}{$A Q$} & 0.000 & $0.001^{* *}$ & $0.377^{* * *}$ & $0.224^{* * *}$ & 0.000 & $0.001^{* *}$ & $0.388^{* * *}$ & $0.228 * * *$ \\
\hline & {$[0.000]$} & {$[0.001]$} & {$[0.028]$} & {$[0.015]$} & {$[0.000]$} & {$[0.001]$} & {$[0.033]$} & {$[0.018]$} \\
\hline \multirow[t]{2}{*}{$\sigma C F O$} & -0.001 & -0.003 & -1.747 & $-0.427^{*}$ & -0.000 & -0.000 & $-2.276^{* *}$ & $-0.740^{* * *}$ \\
\hline & [0.001] & {$[0.002]$} & [1.485] & [0.257] & [0.002] & [0.001] & [0.937] & [0.249] \\
\hline \multirow[t]{2}{*}{ бSale } & $-0.004^{* * *}$ & $-0.006^{* * *}$ & -0.203 & $-0.168 * * *$ & $-0.007 * * *$ & $-0.004^{* * *}$ & -0.107 & $-0.095 * *$ \\
\hline & {$[0.001]$} & {$[0.001]$} & [0.132] & {$[0.048]$} & {$[0.002]$} & {$[0.001]$} & [0.090] & {$[0.045]$} \\
\hline \multirow[t]{2}{*}{ Size } & $-0.000 *$ & 0.000 & $0.330^{* * *}$ & $0.193^{* * *}$ & $-0.001^{* * *}$ & $-0.001^{*}$ & $0.349 * * *$ & $0.206^{* * *}$ \\
\hline & {$[0.000]$} & {$[0.000]$} & [0.017] & {$[0.009]$} & [0.000] & {$[0.000]$} & {$[0.018]$} & {$[0.010]$} \\
\hline \multirow[t]{2}{*}{$B M$} & $-0.003^{* * *}$ & $-0.002^{* * *}$ & -0.025 & $-0.025^{*}$ & $-0.002 * * *$ & $-0.003^{* * *}$ & -0.019 & -0.017 \\
\hline & {$[0.000]$} & {$[0.000]$} & [0.029] & [0.015] & {$[0.000]$} & {$[0.000]$} & {$[0.030]$} & {$[0.016]$} \\
\hline \multirow[t]{2}{*}{ CFConst } & $-0.050 * * *$ & $-0.075^{* * *}$ & $-1.035 * * *$ & $-0.510^{* * *}$ & $-0.048^{* * *}$ & $-0.077 * * *$ & $-0.928 * * *$ & $-0.475^{* * *}$ \\
\hline & {$[0.005]$} & {$[0.006]$} & [0.238] & [0.121] & [0.005] & [0.008] & {$[0.238]$} & {$[0.134]$} \\
\hline \multirow[t]{2}{*}{ Cash } & 0.000 & $-0.032 * * *$ & $-0.783 * * *$ & $-0.490 * * *$ & 0.002 & $-0.033^{* * *}$ & $-0.413^{* * *}$ & $-0.277 * * *$ \\
\hline & [0.001] & {$[0.007]$} & {$[0.140]$} & {$[0.074]$} & [0.001] & {$[0.007]$} & [0.119] & [0.069] \\
\hline \multirow[t]{2}{*}{ Age } & $0.002^{* * *}$ & $0.005^{* * *}$ & $0.672^{* * *}$ & $0.402^{* * *}$ & $0.002^{* * *}$ & $0.005^{* * *}$ & $0.622 * * *$ & $0.374 * * *$ \\
\hline & {$[0.000]$} & {$[0.001]$} & {$[0.041]$} & {$[0.022]$} & {$[0.000]$} & {$[0.001]$} & {$[0.044]$} & {$[0.025]$} \\
\hline Observations & 48892 & 48088 & 49011 & 49011 & 32299 & 31688 & 32376 & 32376 \\
\hline Adjusted/Pseudo R-squared & 0.198 & 0.090 & 0.165 & 0.163 & 0.199 & 0.091 & 0.167 & 0.164 \\
\hline Fixed Effects & C I Y & C I Y & & & C I Y & C I Y & & \\
\hline
\end{tabular}


Table 6. Cash Tax Savings and Efficient Investment

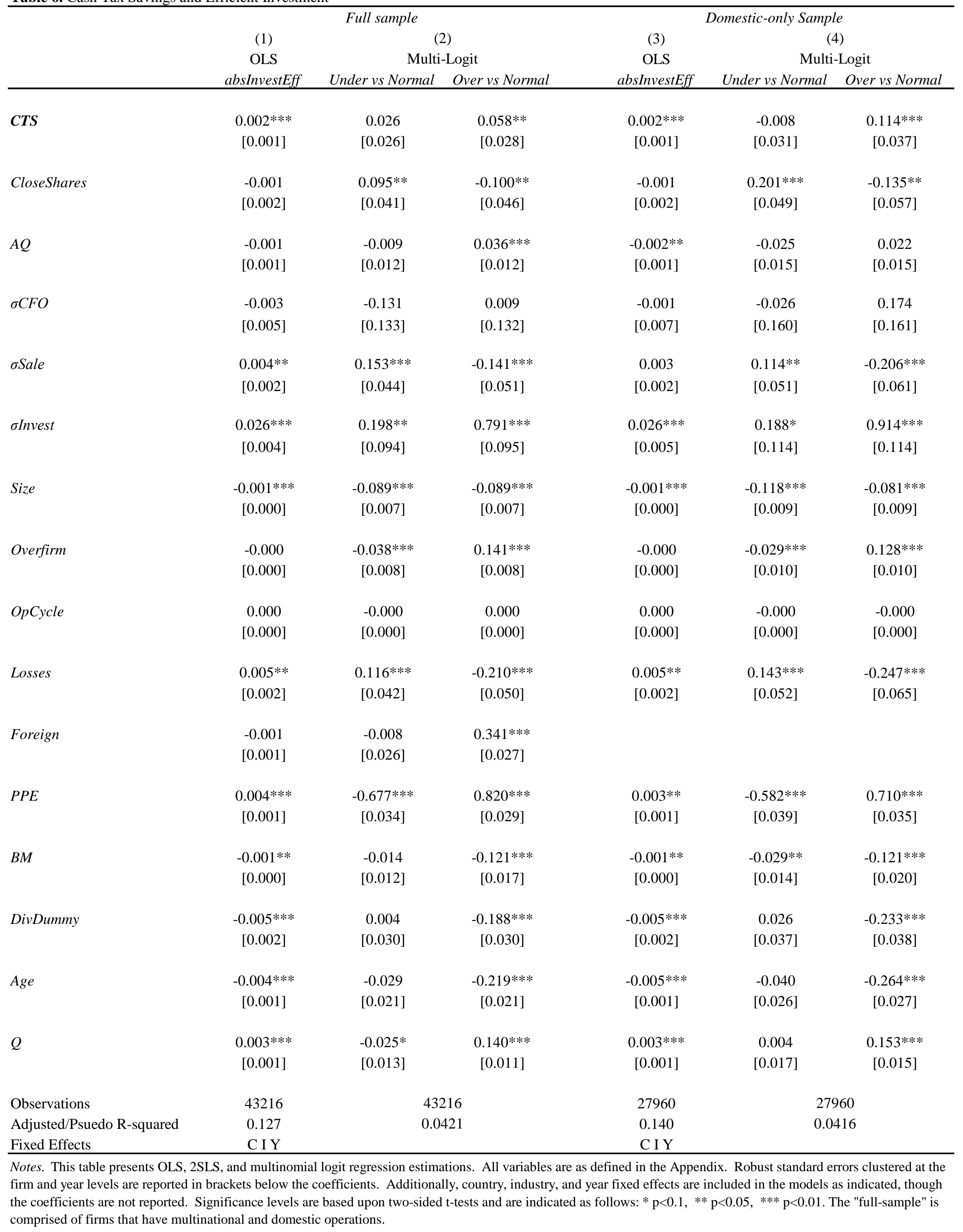


Table 7. Use of Cash Tax Savings and Country-Level Governance

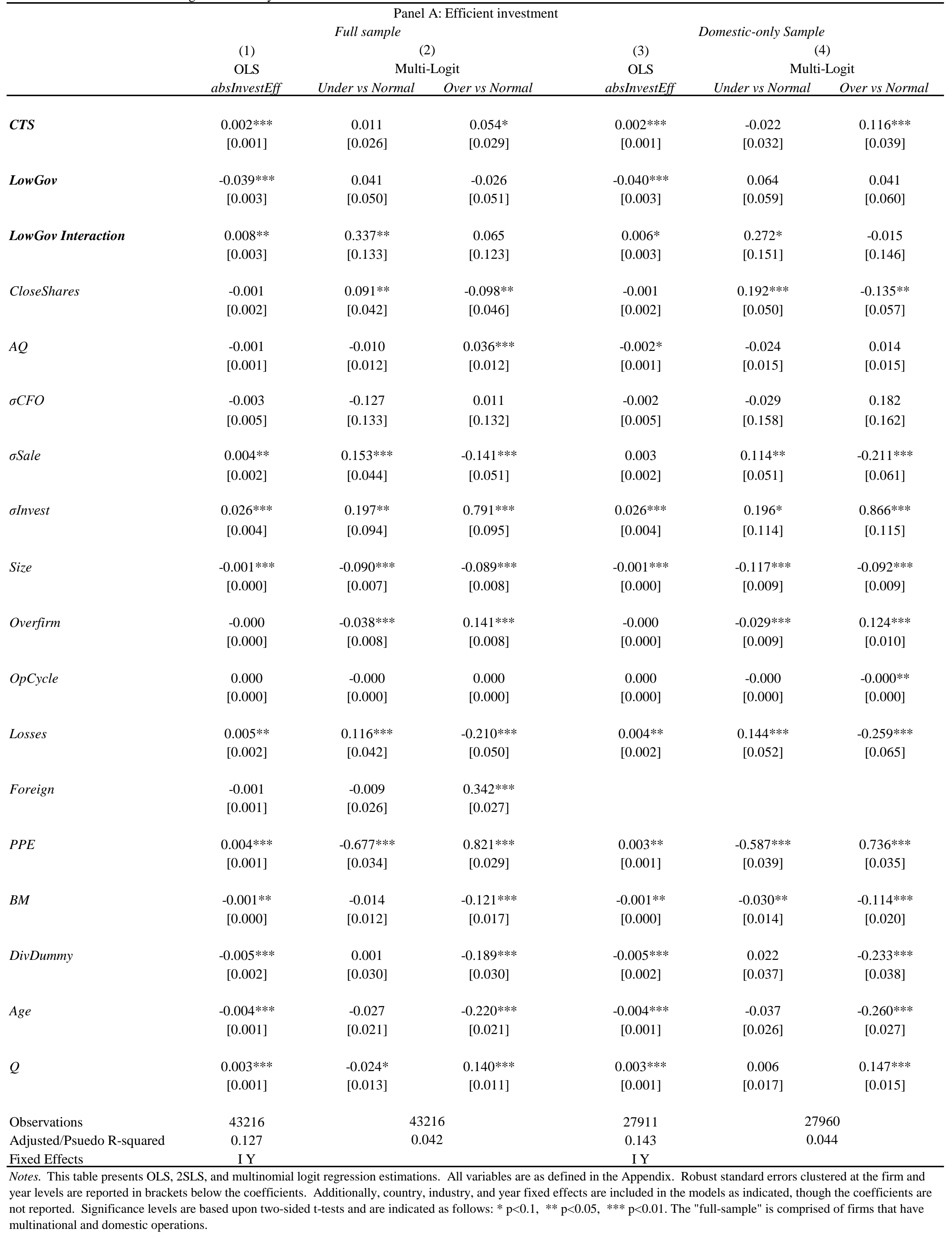


Table 7. Use of Cash Tax Savings and Country-Level Governance

\begin{tabular}{|c|c|c|c|c|}
\hline & & 3: Dividend & & \\
\hline & & & Dome & ample \\
\hline & (1) & (2) & (3) & (4) \\
\hline & CashDiv & Payout & CashDiv & Payout \\
\hline CTS & $-0.003 * * *$ & $-0.004 * * *$ & $-0.003^{* * *}$ & $-0.005 * * *$ \\
\hline & {$[0.000]$} & {$[0.001]$} & {$[0.000]$} & {$[0.001]$} \\
\hline LowGov & 0.003 & $-0.010^{*}$ & $-0.024 * * *$ & $-0.013 * * *$ \\
\hline & {$[0.006]$} & {$[0.005]$} & {$[0.004]$} & {$[0.004]$} \\
\hline LowGov Interaction & $0.005^{* * *}$ & $0.006 * *$ & $0.006 * * *$ & $0.004^{*}$ \\
\hline & {$[0.001]$} & [0.003] & {$[0.002]$} & {$[0.002]$} \\
\hline CloseShares & $0.005^{* * *}$ & $0.010^{* * *}$ & $0.005 * * *$ & $0.011^{* * *}$ \\
\hline & {$[0.001]$} & {$[0.001]$} & {$[0.001]$} & {$[0.002]$} \\
\hline$A Q$ & 0.000 & $0.001 * *$ & 0.000 & $0.001^{*}$ \\
\hline & {$[0.000]$} & {$[0.001]$} & {$[0.000]$} & {$[0.001]$} \\
\hline$\sigma C F O$ & -0.001 & -0.003 & -0.001 & -0.003 \\
\hline & [0.001] & [0.002] & [0.001] & [0.003] \\
\hline oSale & $-0.004 * * *$ & $-0.006 * * *$ & $-0.005 * * *$ & $-0.006 * * *$ \\
\hline & {$[0.001]$} & [0.001] & {$[0.001]$} & {$[0.002]$} \\
\hline Size & $-0.000 *$ & 0.000 & $-0.001 * * *$ & $-0.001 * * *$ \\
\hline & {$[0.000]$} & {$[0.000]$} & {$[0.000]$} & {$[0.000]$} \\
\hline$B M$ & $-0.003 * * *$ & $-0.002 * * *$ & $-0.004 * * *$ & $-0.003 * * *$ \\
\hline & {$[0.000]$} & {$[0.000]$} & {$[0.000]$} & {$[0.000]$} \\
\hline CFConst & $-0.050 * * *$ & $-0.075 * * *$ & $-0.059 * * *$ & $-0.089 * * *$ \\
\hline & {$[0.005]$} & {$[0.006]$} & {$[0.008]$} & {$[0.011]$} \\
\hline Cash & 0.000 & $-0.032 * * *$ & 0.001 & $-0.033 * * *$ \\
\hline & [0.001] & [0.007] & {$[0.001]$} & {$[0.010]$} \\
\hline Age & $0.002 * * *$ & $0.005^{* * *}$ & $0.002 * * *$ & $0.005^{* * *}$ \\
\hline & {$[0.000]$} & {$[0.001]$} & {$[0.001]$} & {$[0.001]$} \\
\hline Observations & 48892 & 48088 & 24120 & 23764 \\
\hline Adjusted R-squared & 0.199 & 0.090 & 0.221 & 0.101 \\
\hline Fixed Effects & I Y & I Y & I Y & I Y \\
\hline
\end{tabular}

Notes. This table presents OLS and 2SLS regression estimations. All variables are as defined in the Appendix. Robust standard errors clustered at the firm and year levels are reported in brackets below the coefficients. Additionally, country, industry, and year fixed effects are included in the models as indicated, though the coefficients are not reported. Significance levels are based upon two-sided t-tests and are indicated as follows: ${ }^{*} \mathrm{p}<0.1,{ }^{* *} \mathrm{p}<0.05, * * * \mathrm{p}<0.01$. The "full-sample" is comprised of firms that have multinational and domestic operations. 
Table 8. Cash Tax Savings and Different Types of Investment for Domestic-Only Firms

\begin{tabular}{|c|c|c|c|}
\hline & $\begin{array}{c}(1) \\
\text { CapEx } \\
\end{array}$ & $\begin{array}{c}(2) \\
\text { Non-CapEx }\end{array}$ & $\begin{array}{c}\text { (3) } \\
\text { Intangibles } \\
\end{array}$ \\
\hline CTS & $\begin{array}{c}0.006^{* * *} \\
{[0.002]}\end{array}$ & $\begin{array}{c}0.004^{* * *} \\
{[0.001]}\end{array}$ & $\begin{array}{c}0.005^{* * *} \\
{[0.001]}\end{array}$ \\
\hline CloseShares & $\begin{array}{c}0.004 \\
{[0.006]}\end{array}$ & $\begin{array}{c}-0.010^{* * *} \\
{[0.002]}\end{array}$ & $\begin{array}{c}-0.008^{* * *} \\
{[0.003]}\end{array}$ \\
\hline$A Q$ & $\begin{array}{c}-0.001 \\
{[0.002]}\end{array}$ & $\begin{array}{c}-0.002 * * * \\
{[0.001]}\end{array}$ & $\begin{array}{c}-0.003^{* * *} \\
{[0.001]}\end{array}$ \\
\hline$\sigma C F O$ & $\begin{array}{c}0.096 * * * \\
{[0.023]}\end{array}$ & $\begin{array}{c}0.011 \\
{[0.010]}\end{array}$ & $\begin{array}{c}0.044^{* * *} \\
{[0.014]}\end{array}$ \\
\hline oSale & $\begin{array}{c}0.020 * * * \\
{[0.006]}\end{array}$ & $\begin{array}{c}-0.004 \\
{[0.003]}\end{array}$ & $\begin{array}{c}-0.006 \\
{[0.004]}\end{array}$ \\
\hline oInvest & $\begin{array}{c}0.019 * * \\
{[0.009]}\end{array}$ & $\begin{array}{c}0.038 * * * \\
{[0.008]}\end{array}$ & $\begin{array}{l}0.021^{* *} \\
{[0.010]}\end{array}$ \\
\hline Size & $\begin{array}{c}0.002 \\
{[0.001]}\end{array}$ & $\begin{array}{c}0.003^{* * *} \\
{[0.001]}\end{array}$ & $\begin{array}{c}0.004^{* * *} \\
{[0.001]}\end{array}$ \\
\hline Overfirm & $\begin{array}{c}0.005^{* * *} \\
{[0.001]}\end{array}$ & $\begin{array}{c}0.002^{* * *} \\
{[0.000]}\end{array}$ & $\begin{array}{c}0.003^{* * *} \\
{[0.000]}\end{array}$ \\
\hline OpCycle & $\begin{array}{c}0.000 \\
{[0.000]}\end{array}$ & $\begin{array}{c}0.000^{* * *} \\
{[0.000]}\end{array}$ & $\begin{array}{c}0.000^{* * *} \\
{[0.000]}\end{array}$ \\
\hline Losses & $\begin{array}{c}-0.021 * * * \\
{[0.004]}\end{array}$ & $\begin{array}{c}-0.000 \\
{[0.002]}\end{array}$ & $\begin{array}{c}-0.018^{* * *} \\
{[0.006]}\end{array}$ \\
\hline$P P E$ & $\begin{array}{c}-0.048 * * * \\
{[0.004]}\end{array}$ & $\begin{array}{c}-0.004^{* *} \\
{[0.002]}\end{array}$ & $\begin{array}{c}-0.008 * * * \\
{[0.003]}\end{array}$ \\
\hline$B M$ & $\begin{array}{c}-0.002^{* *} \\
{[0.001]}\end{array}$ & $\begin{array}{c}-0.001 * * \\
{[0.001]}\end{array}$ & $\begin{array}{c}-0.001 * \\
{[0.001]}\end{array}$ \\
\hline DivDummy & $\begin{array}{c}-0.023 * * * \\
{[0.003]}\end{array}$ & $\begin{array}{c}-0.010 * * * \\
{[0.002]}\end{array}$ & $\begin{array}{c}-0.017^{* * *} \\
{[0.002]}\end{array}$ \\
\hline Age & $\begin{array}{c}-0.025 * * * \\
{[0.002]}\end{array}$ & $\begin{array}{c}-0.005^{* * *} \\
{[0.001]}\end{array}$ & $\begin{array}{c}-0.007^{* * *} \\
{[0.002]}\end{array}$ \\
\hline$Q$ & $\begin{array}{c}0.013^{* * *} \\
{[0.002]}\end{array}$ & $\begin{array}{c}0.006^{* * *} \\
{[0.001]}\end{array}$ & $\begin{array}{c}0.010^{* * *} \\
{[0.002]}\end{array}$ \\
\hline $\begin{array}{l}\text { Observations } \\
\text { Adjusted R-squared } \\
\text { Fixed Effects }\end{array}$ & $\begin{array}{l}29505 \\
0.142 \\
\text { C I Y }\end{array}$ & $\begin{array}{l}29564 \\
0.168 \\
\text { C I Y }\end{array}$ & $\begin{array}{l}27450 \\
0.135 \\
\text { C I Y }\end{array}$ \\
\hline
\end{tabular}

Notes. This table presents OLS regression estimations. All variables are as defined in the Appendix. Robust standard errors clustered at the firm and year levels are reported in brackets below the coefficients. Additionally, country, industry, and year fixed effects are included in the models as indicated, though the coefficients are not reported. Significance levels are based upon two-sided t-tests and are indicated as follows: ${ }^{*} \mathrm{p}<0.1,{ }^{* *} \mathrm{p}<0.05$, $* * * \mathrm{p}<0.01$. 
Table 9. Uses of Cash Tax Savings: Change in Treasury Stock

\section{Full sample}

(1)

chgTreasStock
Domestic-only Sample

(2)

chgTreasStock

$0.000^{*}$

[0.000]

[0.000]

$-0.003^{* * *}$

[0.000]

[0.000]

0.001

[0.001]

[0.001]

$-0.000$

[0.000]

[0.000]

$-0.000$

[0.000]

[0.000]

$0.001^{* * *}$

Size

$0.001^{* * *}$

[0.000]

[0.000]

$-0.001^{* * *}$

$-0.001 * * *$

[0.000]

$B M$

$-0.001 * * *$

$-0.001 * * *$

[0.000]

[0.000]

DivDummy

0.000

$-0.000$

[0.000]

[0.000]

Age

$-0.001^{* * *}$

[0.000]

$-0.001^{* * *}$

[0.000]

Q

$0.001^{* * *}$

$0.001^{* * *}$

[0.000]

[0.000]

Observations

60846

41312

Adjusted R-squared

0.086

0.071

Fixed Effects

C I Y

C I Y

Notes. This table presents OLS and 2SLS regression estimations. ChTreasStock is defined as the change in treasury stock from year $t-1$ to year $t$, deflated by total assets in $t-1$. All other variables are as defined in the Appendix. Robust standard errors clustered at the firm and year levels are reported in brackets below the coefficients. Additionally, country, industry, and year fixed effects are included in the models as indicated, though the coefficients are not reported. Significance levels are based upon two-sided t-tests and are indicated as follows: ${ }^{*} \mathrm{p}<0.1,{ }^{* *} \mathrm{p}<0.05,{ }^{* * *} \mathrm{p}<0.01$. The "full-sample" is comprised of firms that have multinational and domestic operations. 
Table 10. Tax Rate Shocks

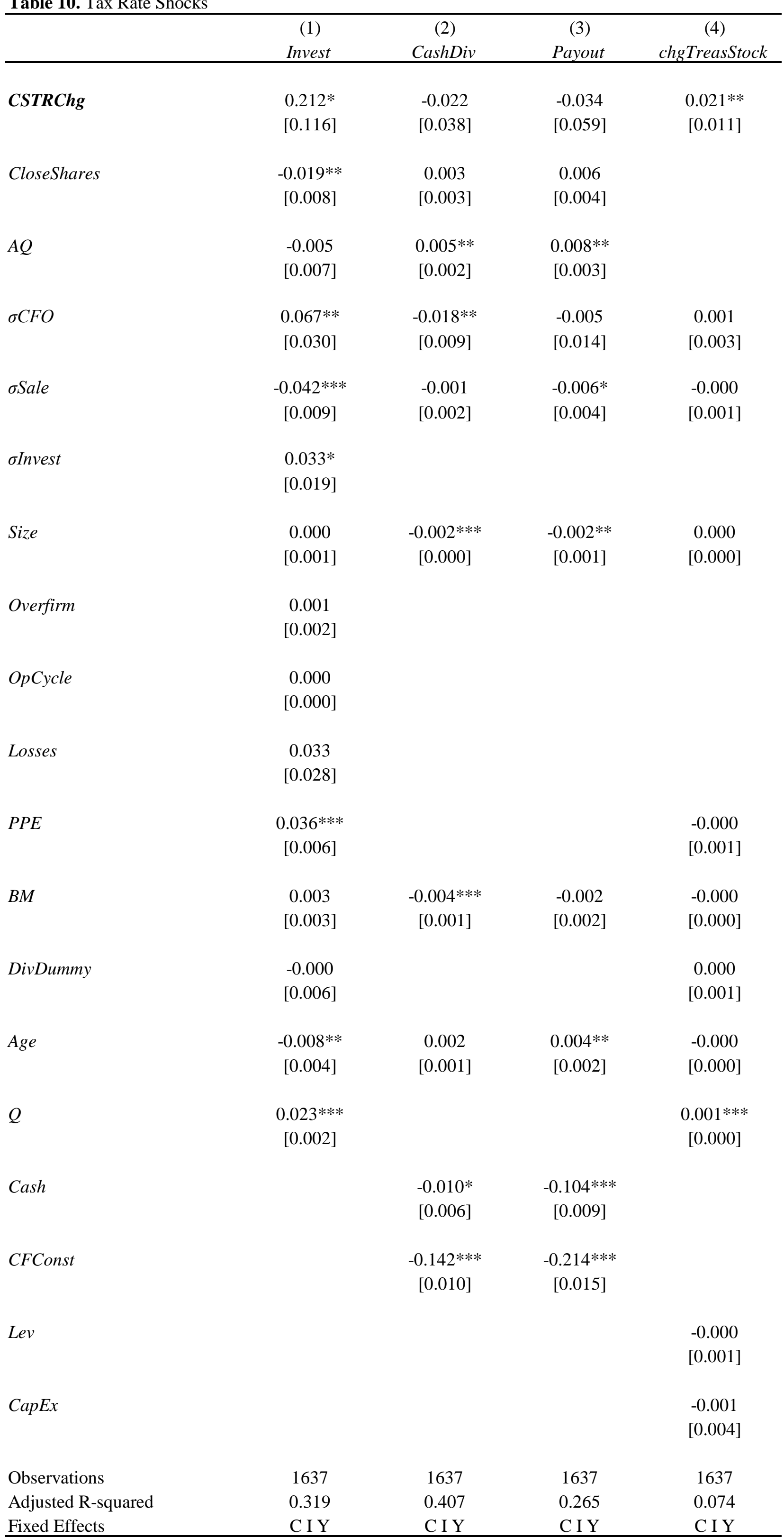

Fixed Effects

C IY

C IY

C IY

C I Y

Notes. This table presents OLS and 2SLS regression estimations. CSTRChg is the change in the corporate statutory rate from year $t-1$ to year $t$. All other variables are as defined in the Appendix. Robust standard errors clustered at the firm and year levels are reported in brackets below the coefficients. Additionally, country, industry, and year fixed effects are included in the models as indicated, though the coefficients are not reported. Significance levels are based upon two-sided t-tests and are indicated as follows: ${ }^{*} \mathrm{p}<0.1,{ }^{* *} \mathrm{p}<0.05,{ }^{* * *} \mathrm{p}<0.01$. 